\title{
Leukotriene receptors (version 2019.4) in the IUPHAR/BPS Guide to Pharmacology Database
}

\author{
Magnus Bäck ${ }^{1}$, Charles Brink², Nan Chiang ${ }^{3}$, Sven-Erik Dahlén ${ }^{1}$, Gordon Dent ${ }^{4}$, Jeffrey Drazen ${ }^{5}$, Jilly F. \\ Evans $^{6}$, Douglas W. P. Hay ${ }^{7}$, Motonao Nakamura ${ }^{8}$, William PowelP, Joshua Rokach ${ }^{10}$, G. Enrico Rovati ${ }^{11}$, \\ Charles N. Serhan ${ }^{5}$, Takao Shimizu ${ }^{8}$ and Takehiko Yokomizo ${ }^{12}$ \\ 1. Karolinska Institutet, Sweden \\ 2. Hopital Marie Lannelongue, France \\ 3. Boston Children's Hospital, USA \\ 4. Keele University, UK \\ 5. Harvard University, USA \\ 6. PharmAkea, USA \\ 7. GlaxoSmithKline, USA \\ 8. University of Tokyo, Japan \\ 9. McGill University, Canada \\ 10. Florida Institute of Technology, USA \\ 11. University of Milan, Italy \\ 12. Juntendo University, Japan
}

\begin{abstract}
The leukotriene receptors (nomenclature as agreed by the NC-IUPHAR subcommittee on Leukotriene Receptors [31, 34]) are activated by the endogenous ligands leukotrienes (LT), synthesized from lipoxygenase metabolism of arachidonic acid. The human $B L T_{1}$ receptor is the high affinity $\mathrm{LTB}_{4}$ receptor whereas the $B L T_{2}$ receptor in addition to being a low-affinity $\mathrm{LTB}_{4}$ receptor also binds several other lipoxygenase-products, such as 12S-HETE, 12S-HPETE, 15S-HETE, and the thromboxane synthase product12-hydroxyheptadecatrienoic acid. The BLT receptors mediate chemotaxis and immunomodulation in several leukocyte populations and are in addition expressed on non-myeloid cells, such as vascular smooth muscle and endothelial cells. In addition to $B L T$ receptors, $\mathrm{LTB}_{4}$ has been reported to bind to the peroxisome proliferator activated receptor (PPAR) $\alpha$ [89] and the vanilloid TRPV1 ligand-gated nonselective cation channel [210]. The receptors for the cysteinylleukotrienes (i.e. $\mathrm{LTC}_{4}, \mathrm{LTD}_{4}$ and $\mathrm{LTE}_{4}$ ) are termed $\mathrm{Cys}_{1} \mathrm{~T}_{1}$ and $\mathrm{CysT}_{2}$ and exhibit distinct expression patterns in human tissues, mediating for example smooth muscle cell contraction, regulation of vascular permeability, and leukocyte activation. There is also evidence in the literature for additional CysLT receptor subtypes, derived from functional in vitro studies, radioligand binding and in mice lacking both $C y s L T_{1}$ and $C y s L T_{2}$ receptors [34]. Cysteinyl-leukotrienes have also been suggested to signal through the $\mathrm{P}_{2} \mathrm{Y}_{12}$ receptor [91, 236, 265], GPR17 [53] and GPR99 [161].
\end{abstract}

\section{Contents}

This is a citation summary for Leukotriene receptors in the Guide to Pharmacology database (GtoPdb). It exists 
purely as an adjunct to the database to facilitate the recognition of citations to and from the database by citation analyzers. Readers will almost certainly want to visit the relevant sections of the database which are given here under database links.

GtoPdb is an expert-driven guide to pharmacological targets and the substances that act on them. GtoPdb is a reference work which is most usefully represented as an on-line database. As in any publication this work should be appropriately cited, and the papers it cites should also be recognized. This document provides a citation for the relevant parts of the database, and also provides a reference list for the research cited by those parts.

Please note that the database version for the citations given in GtoPdb are to the most recent preceding version in which the family or its subfamilies and targets were substantially changed. The links below are to the current version. If you need to consult the cited version, rather than the most recent version, please contact the GtoPdb curators.

\section{Database links}

Leukotriene receptors

http://www.guidetopharmacology.org/GRAC/FamilyDisplayForward?familyld=35

Introduction to Leukotriene receptors

http://www.guidetopharmacology.org/GRAC/FamilyIntroductionForward?familyld=35

Receptors

$\mathrm{BLT}_{1}$ receptor

http://www.guidetopharmacology.org/GRAC/ObjectDisplayForward?objectld=267

$\mathrm{BLT}_{2}$ receptor

http://www.guidetopharmacology.org/GRAC/ObjectDisplayForward?objectld=268

CysLT, receptor

http://www.guidetopharmacology.org/GRAC/ObjectDisplayForward?objectld=269

Cys $\mathrm{LT}_{2}$ receptor

http://www.guidetopharmacology.org/GRAC/ObjectDisplayForward?objectld=270

OXE receptor

http://www.guidetopharmacology.org/GRAC/ObjectDisplayForward?objectld=271

FPR2/ALX

http://www.guidetopharmacology.org/GRAC/ObjectDisplayForward?objectld=223

\section{References}

1. Adamusiak AM, Stasikowska-Kanicka O, Lewandowska-Polak A, Danilewicz M, Wagrowska-Danilewicz M, Jankowski A, Kowalski ML and Pawliczak R. (2012) Expression of arachidonate metabolism enzymes and receptors in nasal polyps of aspirin-hypersensitive asthmatics. Int. Arch. Allergy Immunol. 157: 354-62 [PMID:22123288]

2. Adelroth E, Morris MM, Hargreave FE and O'Byrne PM. (1986) Airway responsiveness to leukotrienes C4 and D4 and to methacholine in patients with asthma and normal controls. N. Engl. J. Med. 315: 480-4 [PMID:3526153]

3. Ahluwalia N, Lin AY, Tager AM, Pruitt IE, Anderson TJ, Kristo F, Shen D, Cruz AR, Aikawa M and Luster $\mathrm{AD}$ et al.. (2007) Inhibited aortic aneurysm formation in BLT1-deficient mice.J. Immunol. 179: 691-7 [PMID:17579092]

4. Aiello RJ, Bourassa PA, Lindsey S, Weng W, Freeman A and Showell HJ. (2002) Leukotriene B4 receptor antagonism reduces monocytic foam cells in mice. Arterioscler. Thromb. Vasc. Biol. 22: 443-9 [PMID:11884288]

5. Akbar GK, Dasari VR, Webb TE, Ayyanathan K, Pillarisetti K, Sandhu AK, Athwal RS, Daniel JL, Ashby B 
and Barnard EA et al.. (1996) Molecular cloning of a novel P2 purinoceptor from human erythroleukemia cells. J. Biol. Chem. 271: 18363-7 [PMID:8702478]

6. Aratake Y, Okuno T, Matsunobu T, Saeki K, Takayanagi R, Furuya S and Yokomizo T. (2012) Helix 8 of leukotriene $B 4$ receptor 1 inhibits ligand-induced internalization. FASEB J. 26: 4068-78 [PMID:22707565]

7. Ariel A, Chiang N, Arita M, Petasis NA and Serhan CN. (2003) Aspirin-triggered lipoxin A4 and B4 analogs block extracellular signal-regulated kinase-dependent TNF-alpha secretion from human T cells. J. Immunol. 170: 6266-72 [PMID:12794159]

8. Bae YS, Lee HY, Jo EJ, Kim JI, Kang HK, Ye RD, Kwak JY and Ryu SH. (2004) Identification of peptides that antagonize formyl peptide receptor-like 1-mediated signaling. J. Immunol. 173: 607-14 [PMID:15210823]

9. Bandeira-Melo C, Hall JC, Penrose JF and Weller PF. (2002) Cysteinyl leukotrienes induce IL-4 release from cord blood-derived human eosinophils. J. Allergy Clin. Immunol. 109: 975-9 [PMID:12063527]

10. Bao L, Gerard NP, Eddy RL Jr, Shows TB and Gerard C. (1992) Mapping of genes for the human C5a receptor (C5AR), human FMLP receptor (FPR), and two FMLP receptor homologue orphan receptors (FPRH1, FPRH2) to chromosome 19. Genomics 13: 437-440 [PMID:1612600]

11. Barajas-Espinosa A, Ni NC, Yan D, Zarini S, Murphy RC and Funk CD. (2012) The cysteinyl leukotriene 2 receptor mediates retinal edema and pathological neovascularization in a murine model of oxygen-induced retinopathy. FASEB J. 26: 1100-9 [PMID:22131271]

12. Barajas-Espinosa A, Ochoa-Cortes F, Moos MP, Ramirez FD, Vanner SJ and Funk CD. (2011) Characterization of the cysteinyl leukotriene 2 receptor in novel expression sites of the gastrointestinal tract. Am. J. Pathol. 178: 2682-9 [PMID:21641390]

13. Barnes NC, Piper PJ and Costello JF. (1984) Comparative effects of inhaled leukotriene C4, leukotriene D4, and histamine in normal human subjects. Thorax 39: 500-4 [PMID:6463929]

14. Barrett NA, Fernandez JM, Maekawa A, Xing W, Li L, Parsons MW, Austen KF and Kanaoka Y. (2012) Cysteinyl leukotriene 2 receptor on dendritic cells negatively regulates ligand-dependent allergic pulmonary inflammation. J. Immunol. 189: 4556-65 [PMID:23002438]

15. Bautz F, Denzlinger C, Kanz L and Möhle R. (2001) Chemotaxis and transendothelial migration of CD34(+) hematopoietic progenitor cells induced by the inflammatory mediator leukotriene D4 are mediated by the 7-transmembrane receptor CysLT1. Blood 97: 3433-40 [PMID:11369634]

16. Beller TC, Friend DS, Maekawa A, Lam BK, Austen KF and Kanaoka Y. (2004) Cysteinyl leukotriene 1 receptor controls the severity of chronic pulmonary inflammation and fibrosis. Proc. Natl. Acad. Sci. U.S.A. 101: 3047-52 [PMID:14970333]

17. Beller TC, Maekawa A, Friend DS, Austen KF and Kanaoka Y. (2004) Targeted gene disruption reveals the role of the cysteinyl leukotriene 2 receptor in increased vascular permeability and in bleomycin-induced pulmonary fibrosis in mice. J. Biol. Chem. 279: 46129-34 [PMID:15328359]

18. Bengtsson AM, Massoumi R and Sjölander A. (2008) Leukotriene D(4) induces AP-1 but not NFkappaB signaling in intestinal epithelial cells. Prostaglandins Other Lipid Mediat. 85: 100-6 [PMID:18083053]

19. Betten A, Bylund J, Christophe T, Cristophe T, Boulay F, Romero A, Hellstrand K and Dahlgren C. (2001) A proinflammatory peptide from Helicobacter pylori activates monocytes to induce lymphocyte dysfunction and apoptosis. J. Clin. Invest. 108: 1221-8 [PMID:11602630]

20. Bevan S, Dichgans M, Wiechmann HE, Gschwendtner A, Meitinger T and Markus HS. (2008) Genetic variation in members of the leukotriene biosynthesis pathway confer an increased risk of ischemic stroke: a replication study in two independent populations. Stroke 39: 1109-14 [PMID:18323512]

21. Birke FW, Meade CJ, Anderskewitz R, Speck GA and Jennewein HM. (2001) In vitro and in vivo pharmacological characterization of BIIL 284, a novel and potent leukotriene B(4) receptor antagonist. J. Pharmacol. Exp. Ther. 297: 458-66 [PMID:11259574]

22. Blättermann S, Peters L, Ottersbach PA, Bock A, Konya V, Weaver CD, Gonzalez A, Schröder R, Tyagi R and Luschnig $P$ et al.. (2012) A biased ligand for OXE-R uncouples $G \alpha$ and $G \beta Y$ signaling within a heterotrimer. Nat. Chem. Biol. 8: 631-8 [PMID:22634634]

23. Boehmler AM, Drost A, Jaggy L, Seitz G, Wiesner T, Denzlinger C, Kanz L and Möhle R. (2009) The 
CysLT1 ligand leukotriene D4 supports alpha4beta1- and alpha5beta1-mediated adhesion and proliferation of CD34+ hematopoietic progenitor cells. J. Immunol. 182: 6789-98 [PMID:19454674]

24. Boie Y, Stocco R, Sawyer N, Greig GM, Kargman S, Slipetz DM, O'Neill GP, Shimizu T, Yokomizo T and Metters KM et al.. (1999) Characterization of the cloned guinea pig leukotriene B4 receptor: comparison to its human orthologue. Eur. J. Pharmacol. 380: 203-13 [PMID:10513580]

25. Bossé Y, Thompson C, McMahon S, Dubois CM, Stankova J and Rola-Pleszczynski M. (2008) Leukotriene D4-induced, epithelial cell-derived transforming growth factor beta1 in human bronchial smooth muscle cell proliferation. Clin. Exp. Allergy 38: 113-21 [PMID:18028462]

26. Braccioni F, Dorman SC, O'byrne PM, Inman MD, Denburg JA, Parameswaran K, Baatjes AJ, Foley R and Gauvreau GM. (2002) The effect of cysteinyl leukotrienes on growth of eosinophil progenitors from peripheral blood and bone marrow of atopic subjects. J. Allergy Clin. Immunol. 110: 96-101 [PMID:12110827]

27. Brancaleone V, Gobbetti T, Cenac N, le Faouder P, Colom B, Flower RJ, Vergnolle N, Nourshargh S and Perretti M. (2013) A vasculo-protective circuit centered on lipoxin A4 and aspirin-triggered 15-epi-lipoxin A4 operative in murine microcirculation. Blood 122: 608-17 [PMID:23733341]

28. Brink C, Dahlén SE, Drazen J, Evans JF, Hay DW, Nicosia S, Serhan CN, Shimizu T and Yokomizo T. (2003) International Union of Pharmacology XXXVII. Nomenclature for leukotriene and lipoxin receptors. Pharmacol. Rev. 55: 195-227 [PMID:12615958]

29. Brink C, Dahlén SE, Drazen J, Evans JF, Hay DW, Rovati GE, Serhan CN, Shimizu T and Yokomizo T. (2004) International Union of Pharmacology XLIV. Nomenclature for the oxoeicosanoid receptor. Pharmacol. Rev. 56: 149-57 [PMID:15001665]

30. Bäck M, Bu DX, Bränström R, Sheikine Y, Yan ZQ and Hansson GK. (2005) Leukotriene B4 signaling through NF-kappaB-dependent BLT1 receptors on vascular smooth muscle cells in atherosclerosis and intimal hyperplasia. Proc. Natl. Acad. Sci. U.S.A. 102: 17501-6 [PMID:16293697]

31. Bäck M, Dahlén SE, Drazen JM, Evans JF, Serhan CN, Shimizu T, Yokomizo T and Rovati GE. (2011) International Union of Basic and Clinical Pharmacology. LXXXIV: leukotriene receptor nomenclature, distribution, and pathophysiological functions. Pharmacol. Rev. 63: 539-84 [PMID:21771892]

32. Bäck M and Hansson GK. (2006) Leukotriene receptors in atherosclerosis. Ann. Med. 38: 493-502 [PMID:17101540]

33. Bäck M, Norel X, Walch L, Gascard J, Mazmanian G, Dahlén S and Brink C. (2000) Antagonist resistant contractions of the porcine pulmonary artery by cysteinyl-leukotrienes. Eur. J. Pharmacol. 401: 381-8 [PMID:10936497]

34. Bäck M, Powell WS, Dahlén SE, Drazen JM, Evans JF, Serhan CN, Shimizu T, Yokomizo T and Rovati GE. (2014) Update on leukotriene, lipoxin and oxoeicosanoid receptors: IUPHAR Review 7. Br. J. Pharmacol. 171: 3551-74 [PMID:24588652]

35. Bürli RW, Xu H, Zou X, Muller K, Golden J, Frohn M, Adlam M, Plant MH, Wong M and McElvain Met al.. (2006) Potent hFPRL1 (ALXR) agonists as potential anti-inflammatory agents. Bioorg. Med. Chem. Lett. 16: 3713-8 [PMID:16697190]

36. Capra V, Accomazzo MR, Ravasi S, Parenti M, Macchia M, Nicosia S and Rovati GE. (2003) Involvement of prenylated proteins in calcium signaling induced by LTD4 in differentiated U937 cells. Prostaglandins Other Lipid Mediat. 71: 235-51 [PMID:14518564]

37. Capra V, Bolla M, Belloni PA, Mezzetti M, Folco GC, Nicosia S and Rovati GE. (1998) Pharmacological characterization of the cysteinyl-leukotriene antagonists CGP 45715A (iralukast) and CGP 57698 in human airways in vitro. Br. J. Pharmacol. 123: 590-8 [PMID:9504401]

38. Capra V, Bäck M, Barbieri SS, Camera M, Tremoli E and Rovati GE. (2013) Eicosanoids and their drugs in cardiovascular diseases: focus on atherosclerosis and stroke. Med Res Rev33: 364-438 [PMID:22434418]

39. Capra V, Nicosia S, Ragnini D, Mezzetti M, Keppler D and Rovati GE. (1998) Identification and characterization of two cysteinyl-leukotriene high affinity binding sites with receptor characteristics in human lung parenchyma. Mol. Pharmacol. 53: 750-8 [PMID:9547367]

40. Capra V, Ravasi S, Accomazzo MR, Citro S, Grimoldi M, Abbracchio MP and Rovati GE. (2005) CysLT1 
receptor is a target for extracellular nucleotide-induced heterologous desensitization: a possible feedback mechanism in inflammation. J. Cell. Sci. 118: 5625-36 [PMID:16306225]

41. Capra V, Ravasi S, Accomazzo MR, Parenti M and Rovati GE. (2004) CysLT1 signal transduction in differentiated U937 cells involves the activation of the small GTP-binding protein Ras. Biochem.

Pharmacol. 67: 1569-77 [PMID:15041474]

42. Carnini C, Accomazzo MR, Borroni E, Vitellaro-Zuccarello L, Durand T, Folco G, Rovati GE, Capra V and Sala A. (2011) Synthesis of cysteinyl leukotrienes in human endothelial cells: subcellular localization and autocrine signaling through the CysLT2 receptor. FASEB J. 25: 3519-28 [PMID:21753081]

43. Cattaneo F, Parisi M and Ammendola R. (2013) Distinct signaling cascades elicited by different formyl Peptide receptor 2 (FPR2) agonists. Int J Mol Sci 14: 7193-230 [PMID:23549262]

44. Chan CC, Ecclestone P, Nicholson DW, Metters KM, Pon DJ and Rodger IW. (1994) Leukotriene D4induced increases in cytosolic calcium in THP-1 cells: dependence on extracellular calcium and inhibition with selective leukotriene D4 receptor antagonists. J. Pharmacol. Exp. Ther. 269: 891-6 [PMID:8014876]

45. Chao SS, Graham SM, Brown CL, Kline JN and Hussain I. (2006) Cysteinyl leukotriene 1 receptor expression in nasal polyps. Ann. Otol. Rhinol. Laryngol. 115: 394-7 [PMID:16739673]

46. Chen K, Le Y, Liu Y, Gong W, Ying G, Huang J, Yoshimura T, Tessarollo L and Wang JM. (2010) A critical role for the g protein-coupled receptor mFPR2 in airway inflammation and immune responses. J. Immunol. 184: 3331-5 [PMID:20200280]

47. Chiang N, Fierro IM, Gronert K and Serhan CN. (2000) Activation of lipoxin A(4) receptors by aspirintriggered lipoxins and select peptides evokes ligand-specific responses in inflammation. J. Exp. Med. 191: 1197-208 [PMID:10748237]

48. Chiang N, Gronert K, Clish CB, O'Brien JA, Freeman MW and Serhan CN. (1999) Leukotriene B4 receptor transgenic mice reveal novel protective roles for lipoxins and aspirin-triggered lipoxins in reperfusion. $J$. Clin. Invest. 104: 309-16 [PMID:10430612]

49. Chiang N, Serhan CN, Dahlén SE, Drazen JM, Hay DW, Rovati GE, Shimizu T, Yokomizo T and Brink C. (2006) The lipoxin receptor ALX: potent ligand-specific and stereoselective actions in vivo. Pharmacol. Rev. 58: 463-87 [PMID:16968948]

50. Chiang N, Takano T, Arita M, Watanabe S and Serhan CN. (2003) A novel rat lipoxin A4 receptor that is conserved in structure and function. Br. J. Pharmacol. 139: 89-98 [PMID:12746227]

51. Chou RC, Kim ND, Sadik CD, Seung E, Lan Y, Byrne MH, Haribabu B, Iwakura Y and Luster AD. (2010) Lipid-cytokine-chemokine cascade drives neutrophil recruitment in a murine model of inflammatory arthritis. Immunity 33: 266-78 [PMID:20727790]

52. Christophe T, Karlsson A, Dugave C, Rabiet MJ, Boulay F and Dahlgren C. (2001) The synthetic peptide Trp-Lys-Tyr-Met-Val-Met-NH2 specifically activates neutrophils through FPRL1/lipoxin A4 receptors and is an agonist for the orphan monocyte-expressed chemoattractant receptor FPRL2. J. Biol. Chem. 276: 21585-93 [PMID:11285256]

53. Ciana P, Fumagalli M, Trincavelli ML, Verderio C, Rosa P, Lecca D, Ferrario S, Parravicini C, Capra V, Gelosa P, Guerrini U, Belcredito S, Cimino M, Sironi L, Tremoli E, Rovati GE, Martini C and Abbracchio MP. (2006) The orphan receptor GPR17 identified as a new dual uracil nucleotides/cysteinyl-leukotrienes receptor. EMBO J. 25: 4615-27 [PMID:16990797]

54. Ciccarelli R, D'Alimonte I, Santavenere C, D'Auro M, Ballerini P, Nargi E, Buccella S, Nicosia S, Folco G and Caciagli $F$ et al.. (2004) Cysteinyl-leukotrienes are released from astrocytes and increase astrocyte proliferation and glial fibrillary acidic protein via cys-LT1 receptors and mitogen-activated protein kinase pathway. Eur. J. Neurosci. 20: 1514-24 [PMID:15355318]

55. Cilibrizzi A, Schepetkin IA, Bartolucci G, Crocetti L, Dal Piaz V, Giovannoni MP, Graziano A, Kirpotina LN, Quinn MT and Vergelli C. (2012) Synthesis, enantioresolution, and activity profile of chiral 6-methyl-2,4disubstituted pyridazin-3(2H)-ones as potent $\mathrm{N}$-formyl peptide receptor agonists. Bioorg. Med. Chem. 20: 3781-92 [PMID:22607879]

56. Clish CB, O'Brien JA, Gronert K, Stahl GL, Petasis NA and Serhan CN. (1999) Local and systemic delivery of a stable aspirin-triggered lipoxin prevents neutrophil recruitment in vivo. Proc. Natl. Acad. Sci. 
U.S.A. 96: 8247-52 [PMID:10393980]

57. Cooke M, Di Cónsoli H, Maloberti P and Cornejo Maciel F. (2013) Expression and function of OXE receptor, an eicosanoid receptor, in steroidogenic cells. Mol. Cell. Endocrinol. 371: 71-8 [PMID:23159987]

58. Cooray SN, Gobbetti T, Montero-Melendez T, McArthur S, Thompson D, Clark AJ, Flower RJ and Perretti M. (2013) Ligand-specific conformational change of the G-protein-coupled receptor ALX/FPR2 determines proresolving functional responses. Proc. Natl. Acad. Sci. U.S.A. 110: 18232-7 [PMID:24108355]

59. Corrigan C, Mallett K, Ying S, Roberts D, Parikh A, Scadding G and Lee T. (2005) Expression of the cysteinyl leukotriene receptors cysLT(1) and cysLT(2) in aspirin-sensitive and aspirin-tolerant chronic rhinosinusitis. J. Allergy Clin. Immunol. 115: 316-22 [PMID:15696087]

60. Cossette C, Patel P, Anumolu JR, Sivendran S, Lee GJ, Gravel S, Graham FD, Lesimple A, Mamer OA and Rokach J et al.. (2008) Human neutrophils convert the sebum-derived polyunsaturated fatty acid Sebaleic acid to a potent granulocyte chemoattractant. J. Biol. Chem. 283: 11234-43 [PMID:18287092]

61. Czech W, Barbisch M, Tenscher K, Schöpf E, Schröder JM and Norgauer J. (1997) Chemotactic 5-oxoeicosatetraenoic acids induce oxygen radical production, Ca2+-mobilization, and actin reorganization in human eosinophils via a pertussis toxin-sensitive G-protein. J. Invest. Dermatol. 108: 108-12 [PMID:8980298]

62. Dahlén SE, Björk J, Hedqvist P, Arfors KE, Hammarström S, Lindgren JA and Samuelsson B. (1981) Leukotrienes promote plasma leakage and leukocyte adhesion in postcapillary venules: in vivo effects with relevance to the acute inflammatory response. Proc. Natl. Acad. Sci. U.S.A. 78: 3887-91 [PMID:6267608]

63. Dallaire MJ, Ferland C, Pagé N, Lavigne S, Davoine F and Laviolette M. (2003) Endothelial cells modulate eosinophil surface markers and mediator release. Eur. Respir. J. 21: 918-24 [PMID:12797482]

64. Dannull J, Schneider T, Lee WT, de Rosa N, Tyler DS and Pruitt SK. (2012) Leukotriene C4 induces migration of human monocyte-derived dendritic cells without loss of immunostimulatory function. Blood 119: 3113-22 [PMID:22323449]

65. Dartt DA, Hodges RR, Li D, Shatos MA, Lashkari K and Serhan CN. (2011) Conjunctival goblet cell secretion stimulated by leukotrienes is reduced by resolvins $\mathrm{D} 1$ and $\mathrm{E} 1$ to promote resolution of inflammation. J. Immunol. 186: 4455-66 [PMID:21357260]

66. Datta YH, Romano M, Jacobson BC, Golan DE, Serhan CN and Ewenstein BM. (1995) Peptidoleukotrienes are potent agonists of von Willebrand factor secretion and P-selectin surface expression in human umbilical vein endothelial cells. Circulation 92: 3304-11 [PMID:7586318]

67. Davenport AP, Alexander SP, Sharman JL, Pawson AJ, Benson HE, Monaghan AE, Liew WC, Mpamhanga CP, Bonner TI and Neubig RR et al.. (2013) International Union of Basic and Clinical Pharmacology. LXXXVIII. G protein-coupled receptor list: recommendations for new pairings with cognate ligands. Pharmacol. Rev. 65: 967-86 [PMID:23686350]

68. Davidson AB, Lee TH, Scanlon PD, Solway J, McFadden Jr ER, Ingram Jr RH, Corey EJ, Austen KF and Drazen JM. (1987) Bronchoconstrictor effects of leukotriene E4 in normal and asthmatic subjects. Am. Rev. Respir. Dis. 135: 333-7 [PMID:3028218]

69. De Yang, Chen Q, Schmidt AP, Anderson GM, Wang JM, Wooters J, Oppenheim JJ and Chertov O. (2000) LL-37, the neutrophil granule- and epithelial cell-derived cathelicidin, utilizes formyl peptide receptor-like 1 (FPRL1) as a receptor to chemoattract human peripheral blood neutrophils, monocytes, and T cells. J. Exp. Med. 192: 1069-74 [PMID:11015447]

70. Deng X, Ueda H, Su SB, Gong W, Dunlop NM, Gao JL, Murphy PM and Wang JM. (1999) A synthetic peptide derived from human immunodeficiency virus type $1 \mathrm{gp} 120$ downregulates the expression and function of chemokine receptors CCR5 and CXCR4 in monocytes by activating the 7-transmembrane Gprotein-coupled receptor FPRL1/LXA4R. Blood 94: 1165-73 [PMID:10438703]

71. Derian CK, Solomon HF, Higgins 3rd JD, Beblavy MJ, Santulli RJ, Bridger GJ, Pike MC, Kroon DJ and Fischman AJ. (1996) Selective inhibition of $\mathrm{N}$-formylpeptide-induced neutrophil activation by carbamatemodified peptide analogues. Biochemistry 35: 1265-9 [PMID:8573582]

72. Devchand PR, Arita M, Hong S, Bannenberg G, Moussignac RL, Gronert K and Serhan CN. (2003) Human ALX receptor regulates neutrophil recruitment in transgenic mice: roles in inflammation and host 
defense. FASEB J. 17: 652-9 [PMID:12665478]

73. Drazen JM, Austen KF, Lewis RA, Clark DA, Goto G, Marfat A and Corey EJ. (1980) Comparative airway and vascular activities of leukotrienes $\mathrm{C}-1$ and $\mathrm{D}$ in vivo and in vitro. Proc. Natl. Acad. Sci. U.S.A.77: 4354-8 [PMID:6933488]

74. Drost AC, Seitz G, Boehmler A, Funk M, Norz KP, Zipfel A, Xue X, Kanz L and Möhle R. (2012) The G protein-coupled receptor CysLT1 mediates chemokine-like effects and prolongs survival in chronic lymphocytic leukemia. Leuk. Lymphoma 53: 665-73 [PMID:21936770]

75. Dufton N, Hannon R, Brancaleone V, Dalli J, Patel HB, Gray M, D'Acquisto F, Buckingham JC, Perretti M and Flower RJ. (2010) Anti-inflammatory role of the murine formyl-peptide receptor 2: ligand-specific effects on leukocyte responses and experimental inflammation. J. Immunol. 184: 2611-9 [PMID:20107188]

76. Díaz-González F, Alten RH, Bensen WG, Brown JP, Sibley JT, Dougados M, Bombardieri S, Durez P, Ortiz $\mathrm{P}$ and de-Miquel $\mathrm{G}$ et al.. (2007) Clinical trial of a leucotriene B4 receptor antagonist, BIIL 284, in patients with rheumatoid arthritis. Ann. Rheum. Dis. 66: 628-32 [PMID:17170051]

77. Eap R, Jacques E, Semlali A, Plante $S$ and Chakir J. (2012) Cysteinyl leukotrienes regulate TGF- $\beta(1)$ and collagen production by bronchial fibroblasts obtained from asthmatic subjects. Prostaglandins Leukot. Essent. Fatty Acids 86: 127-33 [PMID:22316690]

78. Eaton A, Nagy E, Pacault M, Fauconnier J and Bäck M. (2012) Cysteinyl leukotriene signaling through perinuclear CysLT(1) receptors on vascular smooth muscle cells transduces nuclear calcium signaling and alterations of gene expression. J. Mol. Med. 90: 1223-31 [PMID:22527886]

79. Elagoz A, Henderson D, Babu PS, Salter S, Grahames C, Bowers L, Roy MO, Laplante P, Grazzini E and Ahmad $S$ et al.. (2004) A truncated form of CKbeta8-1 is a potent agonist for human formyl peptidereceptor-like 1 receptor. Br. J. Pharmacol. 141: 37-46 [PMID:14662730]

80. Espinosa K, Bossé Y, Stankova J and Rola-Pleszczynski M. (2003) CysLT1 receptor upregulation by TGFbeta and IL-13 is associated with bronchial smooth muscle cell proliferation in response to LTD4. J. Allergy Clin. Immunol. 111: 1032-40 [PMID:12743568]

81. Figueroa DJ, Borish L, Baramki D, Philip G, Austin CP and Evans JF. (2003) Expression of cysteinyl leukotriene synthetic and signalling proteins in inflammatory cells in active seasonal allergic rhinitis. Clin. Exp. Allergy 33: 1380-8 [PMID:14519144]

82. Figueroa DJ, Breyer RM, Defoe SK, Kargman S, Daugherty BL, Waldburger K, Liu Q, Clements M, Zeng Z and O'Neill GP et al.. (2001) Expression of the cysteinyl leukotriene 1 receptor in normal human lung and peripheral blood leukocytes. Am. J. Respir. Crit. Care Med. 163: 226-33 [PMID:11208650]

83. Filep JG, Zouki C, Petasis NA, Hachicha M and Serhan CN. (1999) Anti-inflammatory actions of lipoxin $\mathrm{A}(4)$ stable analogs are demonstrable in human whole blood: modulation of leukocyte adhesion molecules and inhibition of neutrophil-endothelial interactions. Blood 94: 4132-42 [PMID:10590058]

84. Fiore S, Maddox JF, Perez HD and Serhan CN. (1994) Identification of a human cDNA encoding a functional high affinity lipoxin A4 receptor. J. Exp. Med. 180: 253-60 [PMID:8006586]

85. Fiore S, Romano M, Reardon EM and Serhan CN. (1993) Induction of functional lipoxin A4 receptors in HL-60 cells. Blood 81: 3395-403 [PMID:8389617]

86. Fiore S, Ryeom SW, Weller PF and Serhan CN. (1992) Lipoxin recognition sites. Specific binding of labeled lipoxin A4 with human neutrophils. J. Biol. Chem. 267: 16168-76 [PMID:1322894]

87. Fiore S and Serhan CN. (1995) Lipoxin A4 receptor activation is distinct from that of the formyl peptide receptor in myeloid cells: inhibition of CD11/18 expression by lipoxin A4-lipoxin A4 receptor interaction. Biochemistry 34: 16678-86 [PMID:8527441]

88. Forsman H, Andréasson E, Karlsson J, Boulay F, Rabiet MJ and Dahlgren C. (2012) Structural characterization and inhibitory profile of formyl peptide receptor 2 selective peptides descending from a PIP2-binding domain of gelsolin. J. Immunol. 189: 629-37 [PMID:22706076]

89. Forsman $\mathrm{H}$ and Dahlgren C. (2009) Lipoxin A(4) metabolites/analogues from two commercial sources have no effects on TNF-alpha-mediated priming or activation through the neutrophil formyl peptide receptors.

Scand. J. Immunol. 70: 396-402 [PMID:19751275]

90. Foster HR, Fuerst E, Lee TH, Cousins DJ and Woszczek G. (2013) Characterisation of P2Y(12) receptor 
responsiveness to cysteinyl leukotrienes. PLoS ONE 8: e58305 [PMID:23472176]

91. Fredman G, Van Dyke TE and Serhan CN. (2010) Resolvin E1 regulates adenosine diphosphate activation of human platelets. Arterioscler. Thromb. Vasc. Biol. 30: 2005-13 [PMID:20702811]

92. Freer RJ, Day AR, Muthukumaraswamy N, Pinon D, Wu A, Showell HJ and Becker EL. (1982) Formyl peptide chemoattractants: a model of the receptor on rabbit neutrophils. Biochemistry 21: 257-63 [PMID:6280748]

93. Fregonese L, Silvestri M, Sabatini F and Rossi GA. (2002) Cysteinyl leukotrienes induce human eosinophil locomotion and adhesion molecule expression via a CysLT1 receptor-mediated mechanism. Clin. Exp.

Allergy 32: 745-50 [PMID:11994100]

94. Friedrich EB, Tager AM, Liu E, Pettersson A, Owman C, Munn L, Luster AD and Gerszten RE. (2003) Mechanisms of leukotriene B4--triggered monocyte adhesion. Arterioscler. Thromb. Vasc. Biol. 23: 1761-7 [PMID:12947016]

95. Frieri M, Therattil J, Wang SF, Huang CY and Wang YC. (2003) Montelukast inhibits interleukin-5 mRNA expression and cysteinyl leukotriene production in ragweed and mite-stimulated peripheral blood mononuclear cells from patients with asthma. Allergy Asthma Proc 24: 359-66 [PMID:14619337]

96. Fu H, Björkman L, Janmey P, Karlsson A, Karlsson J, Movitz C and Dahlgren C. (2004) The two neutrophil members of the formylpeptide receptor family activate the NADPH-oxidase through signals that differ in sensitivity to a gelsolin derived phosphoinositide-binding peptide. BMC Cell Biol. 5: 50 [PMID:15625007]

97. Fukai H, Ogasawara Y, Migita O, Koga M, Ichikawa K, Shibasaki M, Arinami T and Noguchi E. (2004) Association between a polymorphism in cysteinyl leukotriene receptor 2 on chromosome 13q14 and atopic asthma. Pharmacogenetics 14: 683-90 [PMID:15454733]

98. Galemmo RA Jr, Johnson WH Jr, Learn KS, Lee TD, Huang FC, Campbell HF, Youssefyeh R, O'Rourke SV, Schuessler G and Sweeney DM et al.. (1990) The development of a novel series of (quinolin-2ylmethoxy)phenyl-containing compounds as high-affinity leukotriene receptor antagonists. 3. Structural variation of the acidic side chain to give antagonists of enhanced potency. $J$ Med Chem 33: 2828-41 [PMID:2170649]

99. Gao JL, Chen H, Filie JD, Kozak CA and Murphy PM. (1998) Differential expansion of the N-formylpeptide receptor gene cluster in human and mouse. Genomics 51: 270-6 [PMID:9722950]

100. Gao JL, Guillabert A, Hu J, Le Y, Urizar E, Seligman E, Fang KJ, Yuan X, Imbault V and Communi ๓t al.. (2007) F2L, a peptide derived from heme-binding protein, chemoattracts mouse neutrophils by specifically activating Fpr2, the low-affinity N-formylpeptide receptor. J. Immunol. 178: 1450-6 [PMID:17237393]

101. Gaudreau R, Le Gouill C, Métaoui S, Lemire S, Stankovà J and Rola-Pleszczynski M. (1998) Signalling through the leukotriene B4 receptor involves both alphai and alpha16, but not alphaq or alpha11 G-protein subunits. Biochem. J. 335 ( Pt 1): 15-8 [PMID:9742207]

102. Gauvreau GM, Plitt JR, Baatjes A and MacGlashan DW. (2005) Expression of functional cysteinyl leukotriene receptors by human basophils. J. Allergy Clin. Immunol. 116: 80-7 [PMID:15990778]

103. Gavins FN, Yona S, Kamal AM, Flower RJ and Perretti M. (2003) Leukocyte antiadhesive actions of annexin 1: ALXR- and FPR-related anti-inflammatory mechanisms. Blood 101: $4140-7$ [PMID:12560218]

104. Gewirtz AT, Collier-Hyams LS, Young AN, Kucharzik T, Guilford WJ, Parkinson JF, Williams IR, Neish AS and Madara JL. (2002) Lipoxin a4 analogs attenuate induction of intestinal epithelial proinflammatory gene expression and reduce the severity of dextran sodium sulfate-induced colitis. J. Immunol. 168: 5260-7 [PMID:11994483]

105. Godson C, Mitchell S, Harvey K, Petasis NA, Hogg N and Brady HR. (2000) Cutting edge: lipoxins rapidly stimulate nonphlogistic phagocytosis of apoptotic neutrophils by monocyte-derived macrophages. J. Immunol. 164: 1663-7 [PMID:10657608]

106. Goodarzi K, Goodarzi M, Tager AM, Luster AD and von Andrian UH. (2003) Leukotriene B4 and BLT1 control cytotoxic effector T cell recruitment to inflamed tissues. Nat. Immunol. 4: 965-73 [PMID:12949533]

107. Gore V, Patel P, Chang CT, Sivendran S, Kang N, Ouedraogo YP, Gravel S, Powell WS and Rokach J. (2013) 5-Oxo-ETE receptor antagonists. J. Med. Chem. 56: 3725-32 [PMID:23581530] 
108. Grant GE, Rokach J and Powell WS. (2009) 5-Oxo-ETE and the OXE receptor.Prostaglandins Other Lipid Mediat. 89: 98-104 [PMID:19450703]

109. Griffin M, Weiss JW, Leitch AG, McFadden Jr ER, Corey EJ, Austen KF and Drazen JM. (1983) Effects of leukotriene D on the airways in asthma. N. Engl. J. Med. 308: 436-9 [PMID:6823253]

110. Griffiths RJ, Pettipher ER, Koch K, Farrell CA, Breslow R, Conklyn MJ, Smith MA, Hackman BC, Wimberly DJ and Milici AJ et al.. (1995) Leukotriene B4 plays a critical role in the progression of collagen-induced arthritis. Proc. Natl. Acad. Sci. U.S.A. 92: 517-21 [PMID:7831322]

111. Gronert K, Martinsson-Niskanen T, Ravasi S, Chiang N and Serhan CN. (2001) Selectivity of recombinant human leukotriene $D(4)$, leukotriene $B(4)$, and lipoxin $A(4)$ receptors with aspirin-triggered 15-epi-LXA(4) and regulation of vascular and inflammatory responses. Am. J. Pathol. 158: 3-9 [PMID:11141472]

112. Guilford WJ, Bauman JG, Skuballa W, Bauer S, Wei GP, Davey D, Schaefer C, Mallari C, Terkelsen J and Tseng JL et al.. (2004) Novel 3-oxa lipoxin A4 analogues with enhanced chemical and metabolic stability have anti-inflammatory activity in vivo. J. Med. Chem. 47: 2157-65 [PMID:15056011]

113. Hanson J, Ferreirós N, Pirotte B, Geisslinger G and Offermanns S. (2013) Heterologously expressed formyl peptide receptor 2 (FPR2/ALX) does not respond to lipoxin A4. Biochem. Pharmacol. 85: 1795-802 [PMID:23643932]

114. Harada M, Habata Y, Hosoya M, Nishi K, Fujii R, Kobayashi M and Hinuma S. (2004) N-Formylated humanin activates both formyl peptide receptor-like 1 and 2. Biochem. Biophys. Res. Commun. 324: 25561 [PMID:15465011]

115. Haribabu B, Verghese MW, Steeber DA, Sellars DD, Bock CB and Snyderman R. (2000) Targeted disruption of the leukotriene $B(4)$ receptor in mice reveals its role in inflammation and platelet-activating factor-induced anaphylaxis. J. Exp. Med. 192: 433-8 [PMID:10934231]

116. Haribabu B, Zhelev DV, Pridgen BC, Richardson RM, Ali H and Snyderman R. (1999) Chemoattractant receptors activate distinct pathways for chemotaxis and secretion. Role of G-protein usage. J. Biol. Chem. 274: 37087-92 [PMID:10601267]

117. Hasegawa S, Ichiyama T, Hashimoto K, Suzuki Y, Hirano R, Fukano R and Furukawa S. (2010) Functional expression of cysteinyl leukotriene receptors on human platelets. Platelets 21: 253-9 [PMID:20433311]

118. Hashimoto A, Endo H, Hayashi I, Murakami Y, Kitasato H, Kono S, Matsui T, Tanaka S, Nishimura A and Urabe $\mathrm{K}$ et al.. (2003) Differential expression of leukotriene B4 receptor subtypes (BLT1 and BLT2) in human synovial tissues and synovial fluid leukocytes of patients with rheumatoid arthritis. J. Rheumatol. 30: 1712-8 [PMID:12913925]

119. Hashimoto K, Ichiyama T, Hasegawa M, Hasegawa S, Matsubara T and Furukawa S. (2009) Cysteinyl leukotrienes induce monocyte chemoattractant protein-1 in human monocyte/macrophages via mitogenactivated protein kinase and nuclear factor-kappaB pathways. Int. Arch. Allergy Immunol. 149: 275-82 [PMID:19218821]

120. Hayhoe RP, Kamal AM, Solito E, Flower RJ, Cooper D and Perretti M. (2006) Annexin 1 and its bioactive peptide inhibit neutrophil-endothelium interactions under flow: indication of distinct receptor involvement. Blood 107: 2123-30 [PMID:16278303]

121. He HQ, Liao D, Wang ZG, Wang ZL, Zhou HC, Wang MW and Ye RD. (2013) Functional characterization of three mouse formyl peptide receptors. Mol. Pharmacol. 83: 389-98 [PMID:23160941]

122. He R, Sang $H$ and $Y e ~ R D$. (2003) Serum amyloid A induces IL-8 secretion through a G protein-coupled receptor, FPRL1/LXA4R. Blood 101: 1572-81 [PMID:12393391]

123. He R, Tan L, Browning DD, Wang JM and Ye RD. (2000) The synthetic peptide Trp-Lys-Tyr-Met-Val-DMet is a potent chemotactic agonist for mouse formyl peptide receptor. J. Immunol. 165: 4598-605 [PMID:11035102]

124. Hecht I, Rong J, Sampaio AL, Hermesh C, Rutledge C, Shemesh R, Toporik A, Beiman M, Dassa L and Niv $\mathrm{H}$ et al.. (2009) A novel peptide agonist of formyl-peptide receptor-like 1 (ALX) displays antiinflammatory and cardioprotective effects. J. Pharmacol. Exp. Ther. 328: 426-34 [PMID:19023040]

125. Heise CE, O'Dowd BF, Figueroa DJ, Sawyer N, Nguyen T, Im DS, Stocco R, Bellefeuille JN, Abramovitz M 
and Cheng R et al.. (2000) Characterization of the human cysteinyl leukotriene 2 receptor J. Biol. Chem. 275: 30531-6 [PMID:10851239]

126. Heller EA, Liu E, Tager AM, Sinha S, Roberts JD, Koehn SL, Libby P, Aikawa ER, Chen JQ and Huang P et al.. (2005) Inhibition of atherogenesis in BLT1-deficient mice reveals a role for LTB4 and BLT1 in smooth muscle cell recruitment. Circulation 112: 578-86 [PMID:16043658]

127. Herrera WG. (1990) Vestibular and other balance disorders in multiple sclerosis. Differential diagnosis of disequilibrium and topognostic localization. Neurol Clin 8: 407-20 [PMID:2193219]

128. Herron DK, Goodson T, Bollinger NG, Swanson-Bean D, Wright IG, Staten GS, Thompson AR, Froelich LL and Jackson WT. (1992) Leukotriene B4 receptor antagonists: the LY255283 series of hydroxyacetophenones. J. Med. Chem. 35: 1818-28 [PMID:1316967]

129. Hicks A, Goodnow Jr R, Cavallo G, Tannu SA, Ventre JD, Lavelle D, Lora JM, Satjawatcharaphong J, Brovarney $\mathrm{M}$ and Dabbagh $\mathrm{K}$ et al.. (2010) Effects of LTB4 receptor antagonism on pulmonary inflammation in rodents and non-human primates. Prostaglandins Other Lipid Mediat. 92: 33-43 [PMID:20214997]

130. Hikiji H, Ishii S, Yokomizo T, Takato T and Shimizu T. (2009) A distinctive role of the leukotriene B4 receptor BLT1 in osteoclastic activity during bone loss. Proc. Natl. Acad. Sci. U.S.A. 106: 21294-9 [PMID:19965376]

131. Hoshino M, Izumi T and Shimizu T. (1998) Leukotriene D4 activates mitogen-activated protein kinase through a protein kinase Calpha-Raf-1-dependent pathway in human monocytic leukemia THP-1 cells. J. Biol. Chem. 273: 4878-82 [PMID:9478929]

132. Hosoi T, Koguchi Y, Sugikawa E, Chikada A, Ogawa K, Tsuda N, Suto N, Tsunoda S, Taniguchi T and Ohnuki T. (2002) Identification of a novel human eicosanoid receptor coupled to G(i/o). J. Biol. Chem. 277: 31459-65 [PMID:12065583]

133. Hosoi T, Sugikawa E, Chikada A, Koguchi Y and Ohnuki T. (2005) TG1019/OXE, a Galpha(i/o)-proteincoupled receptor, mediates 5-oxo-eicosatetraenoic acid-induced chemotaxis. Biochem. Biophys. Res. Commun. 334: 987-95 [PMID:16039985]

134. Houard X, Ollivier V, Louedec L, Michel JB and Bäck M. (2009) Differential inflammatory activity across human abdominal aortic aneurysms reveals neutrophil-derived leukotriene B4 as a major chemotactic factor released from the intraluminal thrombus. FASEB J. 23: 1376-83 [PMID:19136615]

135. Hu H, Chen G, Zhang JM, Zhang WP, Zhang L, Ge QF, Yao HT, Ding W, Chen Z and Wei EQ. (2005) Distribution of cysteinyl leukotriene receptor 2 in human traumatic brain injury and brain tumors. Acta Pharmacol. Sin. 26: 685-90 [PMID:15916734]

136. Hu JY, Le Y, Gong W, Dunlop NM, Gao JL, Murphy PM and Wang JM. (2001) Synthetic peptide MMK-1 is a highly specific chemotactic agonist for leukocyte FPRL1. J. Leukoc. Biol. 70: 155-61 [PMID:11435499]

137. Huang WW, Garcia-Zepeda EA, Sauty A, Oettgen HC, Rothenberg ME and Luster AD. (1998) Molecular and biological characterization of the murine leukotriene B4 receptor expressed on eosinophils. J. Exp. Med. 188: 1063-74 [PMID:9743525]

138. Huang XJ, Zhang WP, Li CT, Shi WZ, Fang SH, Lu YB, Chen Z and Wei EQ. (2008) Activation of CysLT receptors induces astrocyte proliferation and death after oxygen-glucose deprivation. Glia 56: 27-37 [PMID:17910051]

139. Hui Y, Cheng Y, Smalera I, Jian W, Goldhahn L, Fitzgerald GA and Funk CD. (2004) Directed vascular expression of human cysteinyl leukotriene 2 receptor modulates endothelial permeability and systemic blood pressure. Circulation 110: 3360-6 [PMID:15545522]

140. Hui Y, Yang G, Galczenski H, Figueroa DJ, Austin CP, Copeland NG, Gilbert DJ, Jenkins NA and Funk CD. (2001) The murine cysteinyl leukotriene 2 (CysLT2) receptor. cDNA and genomic cloning, alternative splicing, and in vitro characterization. J. Biol. Chem. 276: 47489-95 [PMID:11591709]

141. Ichiyama T, Hasegawa M, Hashimoto K, Matsushige T, Hirano R and Furukawa S. (2009) Cysteinyl leukotrienes induce macrophage inflammatory protein-1 in human monocytes/macrophages. Int. Arch. Allergy Immunol. 148: 147-53 [PMID:18802359]

142. Ichiyama T, Hasegawa M, Ueno Y, Makata H, Matsubara T and Furukawa S. (2005) Cysteinyl 
leukotrienes induce monocyte chemoattractant protein 1 in human monocytes/macrophages. Clin. Exp. Allergy 35: 1214-9 [PMID:16164450]

143. Ichiyama T, Kajimoto M, Hasegawa M, Hashimoto K, Matsubara T and Furukawa S. (2007) Cysteinyl leukotrienes enhance tumour necrosis factor-alpha-induced matrix metalloproteinase-9 in human monocytes/macrophages. Clin. Exp. Allergy 37: 608-14 [PMID:17430359]

144. Ihara A, Wada K, Yoneda M, Fujisawa N, Takahashi H and Nakajima A. (2007) Blockade of leukotriene B4 signaling pathway induces apoptosis and suppresses cell proliferation in colon cancer. J. Pharmacol. Sci. 103: 24-32 [PMID:17220595]

145. likura M, Suzukawa M, Yamaguchi M, Sekiya T, Komiya A, Yoshimura-Uchiyama C, Nagase H, Matsushima K, Yamamoto K and Hirai K. (2005) 5-Lipoxygenase products regulate basophil functions: 5Oxo-ETE elicits migration, and leukotriene B(4) induces degranulation. J. Allergy Clin. Immunol. 116: 57885 [PMID:16159627]

146. lizuka Y, Okuno T, Saeki K, Uozaki H, Okada S, Misaka T, Sato T, Toh H, Fukayama M and Takeda Net al.. (2010) Protective role of the leukotriene B4 receptor BLT2 in murine inflammatory colitis FASEB J. 24: 4678-90 [PMID:20667973]

147. lizuka Y, Yokomizo T, Terawaki K, Komine M, Tamaki K and Shimizu T. (2005) Characterization of a mouse second leukotriene B4 receptor, $\mathrm{mBLT2}$ : BLT2-dependent ERK activation and cell migration of primary mouse keratinocytes. J. Biol. Chem. 280: 24816-23 [PMID:15866883]

148. Ingelsson E, Yin L and Bäck M. (2012) Nationwide cohort study of the leukotriene receptor antagonist montelukast and incident or recurrent cardiovascular disease. J. Allergy Clin. Immunol. 129: 702-707.e2 [PMID:22244598]

149. Islam SA, Thomas SY, Hess C, Medoff BD, Means TK, Brander C, Lilly CM, Tager AM and Luster AD. (2006) The leukotriene B4 lipid chemoattractant receptor BLT1 defines antigen-primed T cells in humans. Blood 107: 444-53 [PMID:16179368]

150. Ito S, Ito Y, Katagiri H, Suzuki T, Hoka S, Yokomizo T, Shimizu T and Majima M. (2008) Leukotriene B4/leukotriene B4 receptor pathway is involved in hepatic microcirculatory dysfunction elicited by endotoxin. Shock 30: 87-91 [PMID:18004232]

151. Jackson RH, Morrissey MM, Sills MA and Jarvis MF. (1992) Comparison of antagonist and agonist binding to the leukotriene B4 receptor intact human polymorphonuclear neutrophils (PMN). J. Pharmacol. Exp. Ther. 262: 80-9 [PMID:1320692]

152. Jackson WT, Froelich LL, Boyd RJ, Schrementi JP, Saussy Jr DL, Schultz RM, Sawyer JS, Sofia MJ, Herron DK and Goodson Jr T et al.. (1999) Pharmacologic actions of the second-generation leukotriene B4 receptor antagonist LY293111: in vitro studies. J. Pharmacol. Exp. Ther. 288: 286-94 [PMID:9862783]

153. Jala VR and Haribabu B. (2010) Real-time imaging of leukotriene $B_{4}$ mediated cell migration and BLT1 interactions with $\beta$-arrestin. J Vis Exp [PMID:21206474]

154. Jiang H, Kuang Y, Wu Y, Smrcka A, Simon Ml and Wu D. (1996) Pertussis toxin-sensitive activation of phospholipase $C$ by the C5a and fMet-Leu-Phe receptors. J. Biol. Chem. 271: 13430-4 [PMID:8662841]

155. Jiang W, Hall SR, Moos MP, Cao RY, Ishii S, Ogunyankin KO, Melo LG and Funk CD. (2008) Endothelial cysteinyl leukotriene 2 receptor expression mediates myocardial ischemia-reperfusion injury. Am. J. Pathol. 172: 592-602 [PMID:18276782]

156. Jiang Y, Kanaoka Y, Feng C, Nocka K, Rao S and Boyce JA. (2006) Cutting edge: Interleukin 4dependent mast cell proliferation requires autocrine/intracrine cysteinyl leukotriene-induced signaling. $J$. Immunol. 177: 2755-9 [PMID:16920908]

157. Jones CE. (2005) The OXE receptor: a new therapeutic approach for asthma?Trends Mol Med 11: 266-70 [PMID:15949767]

158. Jones CE, Holden S, Tenaillon L, Bhatia U, Seuwen K, Tranter P, Turner J, Kettle R, Bouhelal R, Charlton S, Nirmala NR, Jarai G and Finan P. (2003) Expression and characterization of a 5-oxo-6E,8Z,11Z,14Zeicosatetraenoic acid receptor highly expressed on human eosinophils and neutrophils. Mol. Pharmacol. 63: 471-477 [PMID:12606753]

159. Kamohara M, Takasaki J, Matsumoto M, Matsumoto Si, Saito T, Soga T, Matsushime H and Furuichi K. 
(2001) Functional characterization of cysteinyl leukotriene CysLT(2) receptor on human coronary artery smooth muscle cells. Biochem. Biophys. Res. Commun. 287: 1088-92 [PMID:11587533]

160. Kamohara M, Takasaki J, Matsumoto M, Saito T, Ohishi T, Ishii H and Furuichi K. (2000) Molecular cloning and characterization of another leukotriene B4 receptor. J. Biol. Chem. 275: 27000-4 [PMID:10889186]

161. Kanaoka Y, Maekawa A and Austen KF. (2013) Identification of GPR99 protein as a potential third cysteinyl leukotriene receptor with a preference for leukotriene E4 ligand. J. Biol. Chem. 288: 10967-72 [PMID:23504326]

162. Kern R, Smith LJ, Patterson R, Krell RD and Bernstein PR. (1986) Characterization of the airway response to inhaled leukotriene D4 in normal subjects. Am. Rev. Respir. Dis. 133: 1127-32 [PMID:3521417]

163. Kihara Y, Yokomizo T, Kunita A, Morishita Y, Fukayama M, Ishii S and Shimizu T. (2010) The leukotriene $\mathrm{B} 4$ receptor, BLT1, is required for the induction of experimental autoimmune encephalomyelitis. Biochem. Biophys. Res. Commun. 394: 673-8 [PMID:20226760]

164. Kim GY, Lee JW, Cho SH, Seo JM and Kim JH. (2009) Role of the low-affinity leukotriene B4 receptor BLT2 in VEGF-induced angiogenesis. Arterioscler. Thromb. Vasc. Biol. 29: 915-20 [PMID:19286633]

165. Kim HJ, Cho SH, Park JS, Lee TH, Lee EJ, Kim YH, Uh ST, Chung IY, Kim MK and Choi ISet al.. (2012) Association analysis of formyl peptide receptor 2 (FPR2) polymorphisms and aspirin exacerbated respiratory diseases. J. Hum. Genet. 57: 247-53 [PMID:22377711]

166. Kim ND, Chou RC, Seung E, Tager AM and Luster AD. (2006) A unique requirement for the leukotriene B4 receptor BLT1 for neutrophil recruitment in inflammatory arthritis. J. Exp. Med. 203: 829-35 [PMID:16567386]

167. Kirpotina LN, Khlebnikov AI, Schepetkin IA, Ye RD, Rabiet MJ, Jutila MA and Quinn MT. (2010) Identification of novel small-molecule agonists for human formyl peptide receptors and pharmacophore models of their recognition. Mol. Pharmacol. 77: 159-70 [PMID:19903830]

168. Kishikawa K, Tateishi N, Maruyama T, Seo R, Toda M and Miyamoto T. (1992) ONO-4057, a novel, orally active leukotriene B4 antagonist: effects on LTB4-induced neutrophil functions. Prostaglandins 44: 261-75 [PMID:1332129]

169. Klein C, Paul JI, Sauvé K, Schmidt MM, Arcangeli L, Ransom J, Trueheart J, Manfredi JP, Broach JR and Murphy AJ. (1998) Identification of surrogate agonists for the human FPRL-1 receptor by autocrine selection in yeast. Nat. Biotechnol. 16: 1334-7 [PMID:9853614]

170. Klotsman M, York TP, Pillai SG, Vargas-Irwin C, Sharma SS, van den Oord EJ and Anderson WH. (2007) Pharmacogenetics of the 5-lipoxygenase biosynthetic pathway and variable clinical response to montelukast. Pharmacogenet. Genomics 17: 189-96 [PMID:17460547]

171. Koike D, Obinata H, Yamamoto A, Takeda S, Komori H, Nara F, Izumi T and Haga T. (2006) 5-Oxoeicosatetraenoic acid-induced chemotaxis: identification of a responsible receptor hGPCR48 and negative regulation by $\mathrm{G}$ protein G(12/13). J. Biochem. 139: 543-9 [PMID:16567419]

172. Kretschmer D, Gleske AK, Rautenberg M, Wang R, Köberle M, Bohn E, Schöneberg T, Rabiet MJ, Boulay F and Klebanoff SJ et al.. (2010) Human formyl peptide receptor 2 senses highly pathogenic Staphylococcus aureus. Cell Host Microbe 7: 463-73 [PMID:20542250]

173. Krishnamoorthy S, Recchiuti A, Chiang N, Fredman G and Serhan CN. (2012) Resolvin D1 receptor stereoselectivity and regulation of inflammation and proresolving microRNAs. Am. J. Pathol. 180: 2018-27 [PMID:22449948]

174. Krishnamoorthy S, Recchiuti A, Chiang N, Yacoubian S, Lee CH, Yang R, Petasis NA and Serhan CN. (2010) Resolvin D1 binds human phagocytes with evidence for proresolving receptors. Proc. Natl. Acad. Sci. U.S.A. 107: 1660-5 [PMID:20080636]

175. Kucharzik T, Gewirtz AT, Merlin D, Madara JL and Williams IR. (2003) Lateral membrane LXA4 receptors mediate LXA4's anti-inflammatory actions on intestinal epithelium. Am. J. Physiol., Cell Physiol. 284: C88896 [PMID:12456400]

176. Kurosaka K, Chen Q, Yarovinsky F, Oppenheim JJ and Yang D. (2005) Mouse cathelin-related antimicrobial peptide chemoattracts leukocytes using formyl peptide receptor-like 1 /mouse formyl peptide 
receptor-like 2 as the receptor and acts as an immune adjuvant. J. Immunol. 174: 6257-65

[PMID:15879124]

177. Kushiya M, Saito K, Kikuchi I, Kobayashi T, Hagiwara K, Kanazawa M and Nagata M. (2006) Differential effects of salbutamol and montelukast on eosinophil adhesion and superoxide anion generation. Int. Arch. Allergy Immunol. 140 Suppl 1: 17-22 [PMID:16772722]

178. Labat C, Ortiz JL, Norel X, Gorenne I, Verley J, Abram TS, Cuthbert NJ, Tudhope SR, Norman P and Gardiner P et al.. (1992) A second cysteinyl leukotriene receptor in human lung.J. Pharmacol. Exp. Ther. 263: 800-5 [PMID:1331415]

179. Lad PM, Olson CV and Smiley PA. (1985) Association of the N-formyl-Met-Leu-Phe receptor in human neutrophils with a GTP-binding protein sensitive to pertussis toxin. Proc. Natl. Acad. Sci. U.S.A. 82: 869-73 [PMID:2983319]

180. Langlois A, Chouinard F, Flamand N, Ferland C, Rola-Pleszczynski M and Laviolette M. (2009) Crucial implication of protein kinase C (PKC)-delta, PKC-zeta, ERK-1/2, and p38 MAPK in migration of human asthmatic eosinophils. J. Leukoc. Biol. 85: 656-63 [PMID:19164129]

181. Lasky-Su J, Neale BM, Franke B, Anney RJ, Zhou K, Maller JB, Vasquez AA, Chen W, Asherson P and Buitelaar J et al.. (2008) Genome-wide association scan of quantitative traits for attention deficit hyperactivity disorder identifies novel associations and confirms candidate gene associations. Am. J. Med. Genet. B Neuropsychiatr. Genet. 147B: 1345-54 [PMID:18821565]

182. Le Y, Gong W, Li B, Dunlop NM, Shen W, Su SB, Ye RD and Wang JM. (1999) Utilization of two seventransmembrane, G protein-coupled receptors, formyl peptide receptor-like 1 and formyl peptide receptor, by the synthetic hexapeptide WKYMVm for human phagocyte activation. J. Immunol. 163: 6777-84 [PMID:10586077]

183. Le Y, Gong W, Tiffany HL, Tumanov A, Nedospasov S, Shen W, Dunlop NM, Gao JL, Murphy PM and Oppenheim JJ et al.. (2001) Amyloid (beta)42 activates a G-protein-coupled chemoattractant receptor, FPR-like-1. J. Neurosci. 21: RC123 [PMID:11160457]

184. Le Y, Jiang S, Hu J, Gong W, Su S, Dunlop NM, Shen W, Li B and Ming Wang J. (2000) N36, a synthetic $\mathrm{N}$-terminal heptad repeat domain of the HIV-1 envelope protein gp41, is an activator of human phagocytes. Clin. Immunol. 96: 236-42 [PMID:10964542]

185. Lee HY, Kim MK, Park KS, Bae YH, Yun J, Park JI, Kwak JY and Bae YS. (2005) Serum amyloid A stimulates matrix-metalloproteinase-9 upregulation via formyl peptide receptor like-1-mediated signaling in human monocytic cells. Biochem. Biophys. Res. Commun. 330: 989-98 [PMID:15809093]

186. Lee TH, Austen KF, Corey EJ and Drazen JM. (1984) Leukotriene E4-induced airway hyperresponsiveness of guinea pig tracheal smooth muscle to histamine and evidence for three separate sulfidopeptide leukotriene receptors. Proc. Natl. Acad. Sci. U.S.A. 81: 4922-5 [PMID:6087352]

187. Levy BD, Fokin VV, Clark JM, Wakelam MJ, Petasis NA and Serhan CN. (1999) Polyisoprenyl phosphate (PIPP) signaling regulates phospholipase $D$ activity: a 'stop' signaling switch for aspirin-triggered lipoxin A4. FASEB J. 13: 903-11 [PMID:10224233]

188. Li RC, Haribabu B, Mathis SP, Kim J and Gozal D. (2011) Leukotriene B4 receptor-1 mediates intermittent hypoxia-induced atherogenesis. Am. J. Respir. Crit. Care Med. 184: 124-31 [PMID:21493735]

189. Lin Q, Ruuska SE, Shaw NS, Dong D and Noy N. (1999) Ligand selectivity of the peroxisome proliferatoractivated receptor alpha. Biochemistry 38: 185-90 [PMID:9890897]

190. Liu M, Chen K, Yoshimura T, Liu Y, Gong W, Wang A, Gao JL, Murphy PM and Wang JM. (2012) Formylpeptide receptors are critical for rapid neutrophil mobilization in host defense against Listeria monocytogenes. Sci Rep 2: 786 [PMID:23139859]

191. Lynch KR, O'Neill GP, Liu Q, Im DS, Sawyer N, Metters KM, Coulombe N, Abramovitz M, Figueroa DJ and Zeng $Z$ et al.. (1999) Characterization of the human cysteinyl leukotriene CysLT1 receptorNature 399: 789-93 [PMID:10391245]

192. Lötzer K, Spanbroek R, Hildner M, Urbach A, Heller R, Bretschneider E, Galczenski H, Evans JF and Habenicht AJ. (2003) Differential leukotriene receptor expression and calcium responses in endothelial cells and macrophages indicate 5-lipoxygenase-dependent circuits of inflammation and atherogenesis. 
Arterioscler. Thromb. Vasc. Biol. 23: e32-6 [PMID:12816882]

193. Maddox JF, Hachicha M, Takano T, Petasis NA, Fokin VV and Serhan CN. (1997) Lipoxin A4 stable analogs are potent mimetics that stimulate human monocytes and THP-1 cells via a G-protein-linked lipoxin A4 receptor. J. Biol. Chem. 272: 6972-8 [PMID:9054386]

194. Maddox JF and Serhan CN. (1996) Lipoxin A4 and B4 are potent stimuli for human monocyte migration and adhesion: selective inactivation by dehydrogenation and reduction. J. Exp. Med. 183: 137-46 [PMID:8551217]

195. Maekawa A, Austen KF and Kanaoka Y. (2002) Targeted gene disruption reveals the role of cysteinyl leukotriene 1 receptor in the enhanced vascular permeability of mice undergoing acute inflammatory responses. J. Biol. Chem. 277: 20820-4 [PMID:11932261]

196. Maekawa A, Balestrieri B, Austen KF and Kanaoka Y. (2009) GPR17 is a negative regulator of the cysteinyl leukotriene 1 receptor response to leukotriene D4. Proc. Natl. Acad. Sci. U.S.A. 106: 11685-90 [PMID:19561298]

197. Maekawa A, Kanaoka Y, Xing W and Austen KF. (2008) Functional recognition of a distinct receptor preferential for leukotriene E4 in mice lacking the cysteinyl leukotriene 1 and 2 receptors. Proc. Natl. Acad. Sci. U.S.A. 105: 16695-700 [PMID:18931305]

198. Magnusson C, Ehrnström R, Olsen J and Sjölander A. (2007) An increased expression of cysteinyl leukotriene 2 receptor in colorectal adenocarcinomas correlates with high differentiation. Cancer Res. 67: 9190-8 [PMID:17909024]

199. Magnusson C, Mezhybovska M, Lörinc E, Fernebro E, Nilbert M and Sjölander A. (2010) Low expression of CysLT1R and high expression of CysLT2R mediate good prognosis in colorectal cancer. Eur. J. Cancer 46: 826-35 [PMID:20064706]

200. Marcinkiewicz J, Grabowska A, Bryniarski K and Chain BM. (1997) Enhancement of CD4+ T-celldependent interleukin-2 production in vitro by murine alveolar macrophages: the role of leukotriene B4. Immunology 91: 369-74 [PMID:9301525]

201. Marder P, Sawyer JS, Froelich LL, Mann LL and Spaethe SM. (1995) Blockade of human neutrophil activation by 2-[2-propyl-3-[3-[2-ethyl-4-(4-fluorophenyl)-5- hydroxyphenoxy]propoxy]phenoxy]benzoic acid (LY293111), a novel leukotriene B4 receptor antagonist. Biochem. Pharmacol. 49: 1683-90 [PMID:7786309]

202. Massoumi R, Larsson $C$ and Sjölander A. (2002) Leukotriene $D(4)$ induces stress-fibre formation in intestinal epithelial cells via activation of RhoA and PKCdelta. J. Cell. Sci. 115: 3509-15 [PMID:12154081]

203. Massoumi R, Nielsen CK, Azemovic D and Sjölander A. (2003) Leukotriene D4-induced adhesion of Caco2 cells is mediated by prostaglandin E2 and upregulation of alpha2beta1-integrin. Exp. Cell Res. 289: 34251 [PMID:14499635]

204. Massoumi R and Sjölander A. (2001) Leukotriene $D(4)$ affects localisation of vinculin in intestinal epithelial cells via distinct tyrosine kinase and protein kinase C controlled events. J. Cell. Sci. 114: 1925-34 [PMID:11329379]

205. Massoumi R and Sjölander A. (1998) The inflammatory mediator leukotriene D4 triggers a rapid reorganisation of the actin cytoskeleton in human intestinal epithelial cells. Eur. J. Cell Biol. 76: 185-91 [PMID:9716265]

206. Mathis SP, Jala VR, Lee DM and Haribabu B. (2010) Nonredundant roles for leukotriene B4 receptors BLT1 and BLT2 in inflammatory arthritis. J. Immunol. 185: 3049-56 [PMID:20656922]

207. Matsunaga Y, Fukuyama S, Okuno T, Sasaki F, Matsunobu T, Asai Y, Matsumoto K, Saeki K, Oike M and Sadamura $Y$ et al.. (2013) Leukotriene B4 receptor BLT2 negatively regulates allergic airway eosinophilia. FASEB J. 27: 3306-14 [PMID:23603839]

208. Matsuyama M, Hayama T, Funao K, Kawahito Y, Sano H, Takemoto Y, Nakatani T and Yoshimura R. (2007) Overexpression of cysteinyl LT1 receptor in prostate cancer and CysLT1R antagonist inhibits prostate cancer cell growth through apoptosis. Oncol. Rep. 18: 99-104 [PMID:17549353]

209. Mattern MR, Mong S, Mong SM, Bartus JO, Sarau HM, Clark MA, Foley JJ and Crooke ST. (1990) Transient activation of topoisomerase I in leukotriene D4 signal transduction in human cells. Biochem. J. 
265: 101-7 [PMID:2154178]

210. McHugh D, McMaster RS, Pertwee RG, Roy S, Mahadevan A, Razdan RK and Ross RA. (2006) Novel compounds that interact with both leukotriene B4 receptors and vanilloid TRPV1 receptors. J. Pharmacol. Exp. Ther. 316: 955-65 [PMID:16207832]

211. Mclntyre TM, Zimmerman GA and Prescott SM. (1986) Leukotrienes C4 and D4 stimulate human endothelial cells to synthesize platelet-activating factor and bind neutrophils. Proc. Natl. Acad. Sci. U.S.A. 83: 2204-8 [PMID:3457383]

212. Mechiche H, Candenas L, Pinto FM, Nazeyrollas P, Clément $C$ and Devillier P. (2004) Characterization of cysteinyl leukotriene receptors on human saphenous veins: antagonist activity of montelukast and its metabolites. J. Cardiovasc. Pharmacol. 43: 113-20 [PMID:14668576]

213. Meliton AY, Munoz NM and Leff AR. (2007) Blockade of avidity and focal clustering of beta 2-integrin by cysteinyl leukotriene antagonism attenuates eosinophil adhesion. J. Allergy Clin. Immunol. 120: 1316-23 [PMID:17904626]

214. Meliton AY, Muñoz NM, Osan CM, Meliton LN and Leff AR. (2010) Leukotriene D4 activates \{beta\}2integrin adhesion in human polymorphonuclear leukocytes. Eur. Respir. J. 35: 402-9 [PMID:19679609]

215. Mellor EA, Frank N, Soler D, Hodge MR, Lora JM, Austen KF and Boyce JA. (2003) Expression of the type 2 receptor for cysteinyl leukotrienes (CysLT2R) by human mast cells: Functional distinction from CysLT1R. Proc. Natl. Acad. Sci. U.S.A. 100: 11589-93 [PMID:13679572]

216. Mellor EA, Maekawa A, Austen KF and Boyce JA. (2001) Cysteinyl leukotriene receptor 1 is also a pyrimidinergic receptor and is expressed by human mast cells. Proc. Natl. Acad. Sci. U.S.A. 98: 7964-9 [PMID:11438743]

217. Miao Z, Premack BA, Wei Z, Wang Y, Gerard C, Showell H, Howard M, Schall TJ and Berahovich R. (2007) Proinflammatory proteases liberate a discrete high-affinity functional FPRL1 (CCR12) ligand from CCL23. J. Immunol. 178: 7395-404 [PMID:17513790]

218. Migeotte I, Communi D and Parmentier M. (2006) Formyl peptide receptors: a promiscuous subfamily of $G$ protein-coupled receptors controlling immune responses. Cytokine Growth Factor Rev. 17: 501-19 [PMID:17084101]

219. Mita $H$, Hasegawa M, Saito $H$ and Akiyama K. (2001) Levels of cysteinyl leukotriene receptor mRNA in human peripheral leucocytes: significantly higher expression of cysteinyl leukotriene receptor 2 mRNA in eosinophils. Clin. Exp. Allergy 31: 1714-23 [PMID:11696047]

220. Miyahara N, Ohnishi H, Matsuda H, Miyahara S, Takeda K, Koya T, Matsubara S, Okamoto M, Dakhama A and Haribabu B et al.. (2008) Leukotriene B4 receptor 1 expression on dendritic cells is required for the development of Th2 responses and allergen-induced airway hyperresponsiveness. J. Immunol. 181: 11708 [PMID:18606670]

221. Miyahara N, Takeda K, Miyahara S, Matsubara S, Koya T, Joetham A, Krishnan E, Dakhama A, Haribabu $B$ and Gelfand EW. (2005) Requirement for leukotriene B4 receptor 1 in allergen-induced airway hyperresponsiveness. Am. J. Respir. Crit. Care Med. 172: 161-7 [PMID:15849325]

222. Miyahara N, Takeda K, Miyahara S, Taube C, Joetham A, Koya T, Matsubara S, Dakhama A, Tager AM and Luster AD et al.. (2005) Leukotriene B4 receptor-1 is essential for allergen-mediated recruitment of CD8+ T cells and airway hyperresponsiveness. J. Immunol. 174: 4979-84 [PMID:15814727]

223. Monneret G, Boumiza R, Gravel S, Cossette C, Bienvenu J, Rokach J and Powell WS. (2005) Effects of prostaglandin $\mathrm{D}(2)$ and 5 -lipoxygenase products on the expression of $C D 203 \mathrm{C}$ and $\mathrm{CD} 11 \mathrm{~b}$ by basophils. $J$. Pharmacol. Exp. Ther. 312: 627-34 [PMID:15388786]

224. Morley AD, King S, Roberts B, Lever S, Teobald B, Fisher A, Cook T, Parker B, Wenlock M and Phillips C et al.. (2012) Lead optimisation of pyrazoles as novel FPR1 antagonists.Bioorg. Med. Chem. Lett. 22: 5326 [PMID:22094028]

225. Muro S, Hamid Q, Olivenstein R, Taha R, Rokach J and Powell WS. (2003) 5-oxo-6,8,11,14eicosatetraenoic acid induces the infiltration of granulocytes into human skin. J. Allergy Clin. Immunol. 112: 768-74 [PMID:14564360]

226. Murphy PM, Ozçelik T, Kenney RT, Tiffany HL, McDermott D and Francke U. (1992) A structural 
homologue of the $\mathrm{N}$-formyl peptide receptor. Characterization and chromosome mapping of a peptide chemoattractant receptor family. J. Biol. Chem. 267: 7637-43 [PMID:1373134]

227. Nagata M, Saito K, Kikuchi I, Hagiwara K and Kanazawa M. (2005) Effect of the cysteinyl leukotriene antagonist pranlukast on transendothelial migration of eosinophils. Int. Arch. Allergy Immunol. 137 SuppI 1: 2-6 [PMID:15947477]

228. Nagata M, Saito K, Tsuchiya K and Sakamoto Y. (2002) Leukotriene D4 upregulates eosinophil adhesion via the cysteinyl leukotriene 1 receptor. J. Allergy Clin. Immunol. 109: 676-80 [PMID:11941318]

229. Nagy E, Andersson DC, Caidahl K, Eriksson MJ, Eriksson P, Franco-Cereceda A, Hansson GK and Bäck M. (2011) Upregulation of the 5-lipoxygenase pathway in human aortic valves correlates with severity of stenosis and leads to leukotriene-induced effects on valvular myofibroblasts. Circulation 123: 1316-25 [PMID:21403093]

230. Nanamori M, Cheng X, Mei J, Sang H, Xuan Y, Zhou C, Wang MW and Ye RD. (2004) A novel nonpeptide ligand for formyl peptide receptor-like 1. Mol. Pharmacol. 66: 1213-22 [PMID:15308762]

231. NCBI. LPHN2 - Ovarian cancer and depression.

232. Ni NC, Yan D, Ballantyne LL, Barajas-Espinosa A, St Amand T, Pratt DA and Funk CD. (2011) A selective cysteinyl leukotriene receptor 2 antagonist blocks myocardial ischemia/reperfusion injury and vascular permeability in mice. J. Pharmacol. Exp. Ther. 339: 768-78 [PMID:21903747]

233. Nielsen CK, Campbell JI, Ohd JF, Mörgelin M, Riesbeck K, Landberg G and Sjölander A. (2005) A novel localization of the G-protein-coupled CysLT1 receptor in the nucleus of colorectal adenocarcinoma cells. Cancer Res. 65: 732-42 [PMID:15705869]

234. Nieves D and Moreno JJ. (2006) Role of 5-lipoxygenase pathway in the regulation of RAW 264.7 macrophage proliferation. Biochem. Pharmacol. 72: 1022-30 [PMID:16934759]

235. Nilsson NE, Tryselius $Y$ and Owman C. (2000) Genomic organization of the leukotriene B(4) receptor locus of human chromosome 14. Biochem. Biophys. Res. Commun. 274: 383-8 [PMID:10913347]

236. Nonaka Y, Hiramoto T and Fujita N. (2005) Identification of endogenous surrogate ligands for human P2Y12 receptors by in silico and in vitro methods. Biochem Biophys Res Commun 337: 281-288 [PMID:16185654]

237. Norgauer J, Barbisch M, Czech W, Pareigis J, Schwenk U and Schröder JM. (1996) Chemotactic 5-oxoicosatetraenoic acids activate a unique pattern of neutrophil responses. Analysis of phospholipid metabolism, intracellular $\mathrm{Ca} 2+$ transients, actin reorganization, superoxide-anion production and receptor up-regulation. Eur. J. Biochem. 236: 1003-9 [PMID:8665888]

238. Norling LV, Dalli J, Flower RJ, Serhan CN and Perretti M. (2012) Resolvin D1 limits polymorphonuclear leukocyte recruitment to inflammatory loci: receptor-dependent actions. Arterioscler. Thromb. Vasc. Biol. 32: 1970-8 [PMID:22499990]

239. Nothacker HP, Wang Z, Zhu Y, Reinscheid RK, Lin SH and Civelli O. (2000) Molecular cloning and characterization of a second human cysteinyl leukotriene receptor: discovery of a subtype selective agonist. Mol. Pharmacol. 58: 1601-8 [PMID:11093801]

240. O'Flaherty JT, Cordes J, Redman J and Thomas MJ. (1993) 5-Oxo-eicosatetraenoate, a potent human neutrophil stimulus. Biochem. Biophys. Res. Commun. 192: 129-34 [PMID:8386504]

241. O'Flaherty JT, Cordes JF, Lee SL, Samuel M and Thomas MJ. (1994) Chemical and biological characterization of oxo-eicosatetraenoic acids. Biochim. Biophys. Acta 1201: 505-15 [PMID:7803484]

242. O'Flaherty JT, Kuroki M, Nixon AB, Wijkander J, Yee E, Lee SL, Smitherman PK, Wykle RL and Daniel LW. (1996) 5-Oxo-eicosatetraenoate is a broadly active, eosinophil-selective stimulus for human granulocytes. J. Immunol. 157: 336-42 [PMID:8683135]

243. O'Flaherty JT, Kuroki M, Nixon AB, Wijkander J, Yee E, Lee SL, Smitherman PK, Wykle RL and Daniel LW. (1996) 5-Oxo-eicosanoids and hematopoietic cytokines cooperate in stimulating neutrophil function and the mitogen-activated protein kinase pathway. J. Biol. Chem. 271: 17821-8 [PMID:8663432]

244. O'Flaherty JT, Rogers LC, Paumi CM, Hantgan RR, Thomas LR, Clay CE, High K, Chen YQ, Willingham $\mathrm{MC}$ and Smitherman PK et al.. (2005) 5-Oxo-ETE analogs and the proliferation of cancer cells.Biochim. Biophys. Acta 1736: 228-36 [PMID:16154383] 
245. O'Flaherty JT, Taylor JS and Kuroki M. (2000) The coupling of 5-oxo-eicosanoid receptors to heterotrimeric G proteins. J. Immunol. 164: 3345-52 [PMID:10706729]

246. O'Flaherty JT, Taylor JS and Thomas MJ. (1998) Receptors for the 5-oxo class of eicosanoids in neutrophils. J. Biol. Chem. 273: 32535-41 [PMID:9829988]

247. Ogasawara H, Ishii S, Yokomizo T, Kakinuma T, Komine M, Tamaki K, Shimizu T and Izumi T. (2002) Characterization of mouse cysteinyl leukotriene receptors $\mathrm{mCysLT1}$ and $\mathrm{mCysLT2:}$ differential pharmacological properties and tissue distribution. J. Biol. Chem. 277: 18763-8 [PMID:11854273]

248. Ohd JF, Nielsen CK, Campbell J, Landberg G, Löfberg H and Sjölander A. (2003) Expression of the leukotriene D4 receptor CysLT1, COX-2, and other cell survival factors in colorectal adenocarcinomas. Gastroenterology 124: 57-70 [PMID:12512030]

249. Okamoto F, Saeki K, Sumimoto H, Yamasaki S and Yokomizo T. (2010) Leukotriene B4 augments and restores Fc gammaRs-dependent phagocytosis in macrophages. J. Biol. Chem. 285: 41113-21 [PMID:20959460]

250. Okuno T, Ago H, Terawaki K, Miyano M, Shimizu T and Yokomizo T. (2003) Helix 8 of the leukotriene B4 receptor is required for the conformational change to the low affinity state after G-protein activation. J. Biol. Chem. 278: 41500-9 [PMID:12902330]

251. Okuno T, lizuka Y, Okazaki H, Yokomizo T, Taguchi R and Shimizu T. (2008) 12(S)-Hydroxyheptadeca$5 Z, 8 \mathrm{E}, 10 \mathrm{E}-$-trienoic acid is a natural ligand for leukotriene B4 receptor 2. J. Exp. Med. 205: 759-66 [PMID:18378794]

252. Ortiz JL, Gorenne I, Cortijo J, Seller A, Labat C, Sarria B, Abram TS, Gardiner PJ, Morcillo E and Brink C. (1995) Leukotriene receptors on human pulmonary vascular endothelium. Br. J. Pharmacol. 115: 1382-6 [PMID:8564195]

253. Oyoshi MK, He R, Kanaoka Y, EIKhal A, Kawamoto S, Lewis CN, Austen KF and Geha RS. (2012) Eosinophil-derived leukotriene $\mathrm{C} 4$ signals via type 2 cysteinyl leukotriene receptor to promote skin fibrosis in a mouse model of atopic dermatitis. Proc. Natl. Acad. Sci. U.S.A. 109: 4992-7 [PMID:22416124]

254. Oyoshi MK, He R, Li Y, Mondal S, Yoon J, Afshar R, Chen M, Lee DM, Luo HR and Luster A£t al.. (2012) Leukotriene B4-driven neutrophil recruitment to the skin is essential for allergic skin inflammation. Immunity 37: 747-58 [PMID:23063331]

255. Panettieri RA, Tan EM, Ciocca V, Luttmann MA, Leonard TB and Hay DW. (1998) Effects of LTD4 on human airway smooth muscle cell proliferation, matrix expression, and contraction In vitro: differential sensitivity to cysteinyl leukotriene receptor antagonists. Am. J. Respir. Cell Mol. Biol. 19: 453-61 [PMID:9730873]

256. Parameswaran K, Cox G, Radford K, Janssen LJ, Sehmi R and O'Byrne PM. (2002) Cysteinyl leukotrienes promote human airway smooth muscle migration. Am. J. Respir. Crit. Care Med. 166: 738-42 [PMID:12204874]

257. Parhamifar L, Jeppsson B and Sjölander A. (2005) Activation of cPLA2 is required for leukotriene D4induced proliferation in colon cancer cells. Carcinogenesis 26: 1988-98 [PMID:15975962]

258. Park JS, Chang HS, Park CS, Lee JH, Lee YM, Choi JH, Park HS, Kim LH, Park BL and Choi YHet al.. (2005) Association analysis of cysteinyl-leukotriene receptor 2 (CYSLTR2) polymorphisms with aspirin intolerance in asthmatics. Pharmacogenet. Genomics 15: 483-92 [PMID:15970796]

259. Parmentier CN, Fuerst E, McDonald J, Bowen H, Lee TH, Pease JE, Woszczek G and Cousins DJ. (2012) Human $T(H) 2$ cells respond to cysteinyl leukotrienes through selective expression of cysteinyl leukotriene receptor 1. J. Allergy Clin. Immunol. 129: 1136-42 [PMID:22391114]

260. Partida-Sánchez S, Cockayne DA, Monard S, Jacobson EL, Oppenheimer N, Garvy B, Kusser K, Goodrich S, Howard M and Harmsen A et al.. (2001) Cyclic ADP-ribose production by CD38 regulates intracellular calcium release, extracellular calcium influx and chemotaxis in neutrophils and is required for bacterial clearance in vivo. Nat. Med. 7: 1209-16 [PMID:11689885]

261. Partidá-Sánchez S, Rivero-Nava L, Shi G and Lund FE. (2007) CD38: an ecto-enzyme at the crossroads of innate and adaptive immune responses. Adv. Exp. Med. Biol. 590: 171-83 [PMID:17191385]

262. Paruchuri S, Broom O, Dib K and Sjölander A. (2005) The pro-inflammatory mediator leukotriene D4 
induces phosphatidylinositol 3-kinase and Rac-dependent migration of intestinal epithelial cells. J. Biol. Chem. 280: 13538-44 [PMID:15657050]

263. Paruchuri S, Hallberg B, Juhas M, Larsson C and Sjölander A. (2002) Leukotriene D(4) activates MAPK through a Ras-independent but PKCepsilon-dependent pathway in intestinal epithelial cells. J. Cell. Sci. 115: 1883-93 [PMID:11956320]

264. Paruchuri S and Sjölander A. (2003) Leukotriene D4 mediates survival and proliferation via separate but parallel pathways in the human intestinal epithelial cell line Int 407. J. Biol. Chem. 278: 45577-85 [PMID:12912998]

265. Paruchuri S, Tashimo H, Feng C, Maekawa A, Xing W, Jiang Y, Kanaoka Y, Conley P and Boyce JA. (2009) Leukotriene E4-induced pulmonary inflammation is mediated by the P2Y12 receptor. J. Exp. Med. 206: 2543-55 [PMID:19822647]

266. Patel P, Cossette C, Anumolu JR, Gravel S, Lesimple A, Mamer OA, Rokach J and Powell WS. (2008) Structural requirements for activation of the 5-oxo-6E,8Z, 11Z,14Z-eicosatetraenoic acid (5-oxo-ETE) receptor: identification of a mead acid metabolite with potent agonist activity. J. Pharmacol. Exp. Ther. 325: 698-707 [PMID:18292294]

267. Patel P, Reddy CN, Gore V, Chourey S, Ye Q, Ouedraogo YP, Gravel S, Powell WS and Rokach J. (2014) Two Potent OXE-R Antagonists: Assignment of Stereochemistry. ACS Med Chem Lett 5: 815-9 [PMID:25050171]

268. Pedersen KE, Bochner BS and Undem BJ. (1997) Cysteinyl leukotrienes induce P-selectin expression in human endothelial cells via a non-CysLT1 receptor-mediated mechanism. J. Pharmacol. Exp. Ther. 281: 655-62 [PMID:9152370]

269. Perng DW, Wu YC, Chang KT, Wu MT, Chiou YC, Su KC, Perng RP and Lee YC. (2006) Leukotriene C4 induces TGF-beta1 production in airway epithelium via p38 kinase pathway. Am. J. Respir. Cell Mol. Biol. 34: 101-7 [PMID:16179583]

270. Perretti M, Chiang N, La M, Fierro IM, Marullo S, Getting SJ, Solito E and Serhan CN. (2002) Endogenous lipid- and peptide-derived anti-inflammatory pathways generated with glucocorticoid and aspirin treatment activate the lipoxin A4 receptor. Nat. Med. 8: 1296-302 [PMID:12368905]

271. Petri MH, Laguna-Fernandez A, Tseng CN, Hedin U, Perretti M and Bäck M. (2015) Aspirin-triggered 15epi-lipoxin $\mathrm{A}_{4}$ signals through FPR2/ALX in vascular smooth muscle cells and protects against intimal hyperplasia after carotid ligation. Int. J. Cardiol. 179: 370-2 [PMID:25464488]

272. Pillai SG, Cousens DJ, Barnes AA, Buckley PT, Chiano MN, Hosking LK, Cameron LA, Fling ME, Foley JJ and Green A et al.. (2004) A coding polymorphism in the CYSLT2 receptor with reduced affinity to LTD4 is associated with asthma. Pharmacogenetics 14: 627-33 [PMID:15475736]

273. Pinilla C, Edwards BS, Appel JR, Yates-Gibbins T, Giulianotti MA, Medina-Franco JL, Young SM, Santos RG, Sklar LA and Houghten RA. (2013) Selective agonists and antagonists of formylpeptide receptors: duplex flow cytometry and mixture-based positional scanning libraries. Mol. Pharmacol. 84: 314-24 [PMID:23788657]

274. Planagumà A, Domenech T, Jover I, Ramos I, Sentellas S, Malhotra R and Miralpeix M. (2013) Lack of activity of 15-epi-lipoxin A4 on FPR2/ALX and CysLT1 receptors in interleukin-8-driven human neutrophil function. Clin. Exp. Immunol. 173: 298-309 [PMID:23607720]

275. Pollock K and Creba J. (1990) Leukotriene D4 induced calcium changes in U937 cells may utilize mechanisms additional to inositol phosphate production that are pertussis toxin insensitive but are blocked by phorbol myristate acetate. Cell. Signal. 2: 563-8 [PMID:1964390]

276. Porreca E, Di Febbo C, Di Sciullo A, Angelucci D, Nasuti M, Vitullo P, Reale M, Conti P, Cuccurullo F and Poggi A. (1996) Cysteinyl leukotriene D4 induced vascular smooth muscle cell proliferation: a possible role in myointimal hyperplasia. Thromb. Haemost. 76: 99-104 [PMID:8819260]

277. Powell WS, Chung D and Gravel S. (1995) 5-Oxo-6,8,11,14-eicosatetraenoic acid is a potent stimulator of human eosinophil migration. J. Immunol. 154: 4123-32 [PMID:7706749]

278. Powell WS, Gravel S and Gravelle F. (1995) Formation of a 5-oxo metabolite of 5,8,11,14,17eicosapentaenoic acid and its effects on human neutrophils and eosinophils. J. Lipid Res. 36: 2590-8 
[PMID:8847485]

279. Powell WS, Gravel S and Halwani F. (1999) 5-oxo-6,8,11,14-eicosatetraenoic acid is a potent stimulator of L-selectin shedding, surface expression of CD11b, actin polymerization, and calcium mobilization in human eosinophils. Am. J. Respir. Cell Mol. Biol. 20: 163-70 [PMID:9870930]

280. Powell WS, Gravel S, Halwani F, Hii CS, Huang ZH, Tan AM and Ferrante A. (1997) Effects of 5-oxo6,8,11,14-eicosatetraenoic acid on expression of CD11b, actin polymerization, and adherence in human neutrophils. J. Immunol. 159: 2952-9 [PMID:9300719]

281. Powell WS, Gravel S, Khanapure SP and Rokach J. (1999) Biological inactivation of 5-oxo-6,8,11,14eicosatetraenoic acid by human platelets. Blood 93: 1086-96 [PMID:9920859]

282. Powell WS, Gravel S, MacLeod RJ, Mills E and Hashefi M. (1993) Stimulation of human neutrophils by 5oxo-6,8,11,14-eicosatetraenoic acid by a mechanism independent of the leukotriene B4 receptor. J. Biol. Chem. 268: 9280-6 [PMID:8387490]

283. Powell WS, Gravelle F and Gravel S. (1992) Metabolism of 5(S)-hydroxy-6,8,11,14-eicosatetraenoic acid and other $5(\mathrm{~S})$-hydroxyeicosanoids by a specific dehydrogenase in human polymorphonuclear leukocytes. J. Biol. Chem. 267: 19233-41 [PMID:1326548]

284. Powell WS, MacLeod RJ, Gravel S, Gravelle F and Bhakar A. (1996) Metabolism and biologic effects of 5oxoeicosanoids on human neutrophils. J. Immunol. 156: 336-42 [PMID:8598482]

285. Powell WS and Rokach J. (2013) The eosinophil chemoattractant 5-oxo-ETE and the OXE receptor.Prog. Lipid Res. 52: 651-65 [PMID:24056189]

286. Prat C, Bestebroer J, de Haas CJ, van Strijp JA and van Kessel KP. (2006) A new staphylococcal antiinflammatory protein that antagonizes the formyl peptide receptor-like 1. J. Immunol. 177: 8017-26 [PMID:17114475]

287. Price D, Musgrave SD, Shepstone L, Hillyer EV, Sims EJ, Gilbert RF, Juniper EF, Ayres JG, Kemp L and Blyth A et al.. (2011) Leukotriene antagonists as first-line or add-on asthma-controller therapy.N. Engl. J. Med. 364: 1695-707 [PMID:21542741]

288. Profita M, Sala A, Bonanno A, Siena L, Ferraro M, Di Giorgi R, Montalbano AM, Albano GD, Gagliardo R and Gjomarkaj M. (2008) Cysteinyl leukotriene-1 receptor activation in a human bronchial epithelial cell line leads to signal transducer and activator of transcription 1-mediated eosinophil adhesion. J. Pharmacol. Exp. Ther. 325: 1024-30 [PMID:18305014]

289. Provost V, Langlois A, Chouinard F, Rola-Pleszczynski M, Chakir J, Flamand N and Laviolette M. (2012) Leukotriene D4 and interleukin-13 cooperate to increase the release of eotaxin-3 by airway epithelial cells. PLoS ONE 7: e43544 [PMID:22952702]

290. Pérez-Novo CA, Claeys C, Van Cauwenberge P and Bachert C. (2006) Expression of eicosanoid receptors subtypes and eosinophilic inflammation: implication on chronic rhinosinusitis. Respir. Res. 7: 75 [PMID:16689996]

291. Qi LL, Fang SH, Shi WZ, Huang XQ, Zhang XY, Lu YB, Zhang WP and Wei EQ. (2011) CysLT2 receptormediated AQP4 up-regulation is involved in ischemic-like injury through activation of ERK and p38 MAPK in rat astrocytes. Life Sci. 88: 50-6 [PMID:21055410]

292. Qiu FH, Devchand PR, Wada K and Serhan CN. (2001) Aspirin-triggered lipoxin A4 and lipoxin A4 upregulate transcriptional corepressor NAB1 in human neutrophils. FASEB J. 15: 2736-8 [PMID:11687510]

293. Quehenberger O, Prossnitz ER, Cavanagh SL, Cochrane CG and Ye RD. (1993) Multiple domains of the $\mathrm{N}$-formyl peptide receptor are required for high-affinity ligand binding. Construction and analysis of chimeric N-formyl peptide receptors. J. Biol. Chem. 268: 18167-75 [PMID:8349692]

294. Rabiet MJ, Huet E and Boulay F. (2005) Human mitochondria-derived N-formylated peptides are novel agonists equally active on FPR and FPRL1, while Listeria monocytogenes-derived peptides preferentially activate FPR. Eur. J. Immunol. 35: 2486-95 [PMID:16025565]

295. Ravasi S, Capra V, Mezzetti M, Nicosia S and Rovati GE. (2000) A kinetic binding study to evaluate the pharmacological profile of a specific leukotriene $\mathrm{C}(4)$ binding site not coupled to contraction in human lung parenchyma. Mol. Pharmacol. 57: 1182-9 [PMID:10825389]

296. Ravasi S, Capra V, Panigalli T, Rovati GE and Nicosia S. (2002) Pharmacological differences among 
CysLT(1) receptor antagonists with respect to $\operatorname{LTC}(4)$ and $\operatorname{LTD}(4)$ in human lung parenchyma. Biochem. Pharmacol. 63: 1537-46 [PMID:11996896]

297. Ravasi S, Citro S, Viviani B, Capra V and Rovati GE. (2006) CysLT1 receptor-induced human airway smooth muscle cells proliferation requires ROS generation, EGF receptor transactivation and ERK1/2 phosphorylation. Respir. Res. 7: 42 [PMID:16553950]

298. Resnati M, Pallavicini I, Wang JM, Oppenheim J, Serhan CN, Romano M and Blasi F. (2002) The fibrinolytic receptor for urokinase activates the $G$ protein-coupled chemotactic receptor FPRL1/LXA4R. Proc. Natl. Acad. Sci. U.S.A. 99: 1359-64 [PMID:11818541]

299. Richards IM, Sun FF, Taylor BM, Shields SK, Griffin RL, Morris J, Wishka DG, Smith HW, Johnson RA and Dunn CJ. (1991) Contribution of leukotriene B4 to airway inflammation and the effect of antagonists. Ann. N. Y. Acad. Sci. 629: 274-87 [PMID:1659282]

300. Romano M, Maddox JF and Serhan CN. (1996) Activation of human monocytes and the acute monocytic leukemia cell line (THP-1) by lipoxins involves unique signaling pathways for lipoxin A4 versus lipoxin B4: evidence for differential Ca2+ mobilization. J. Immunol. 157: 2149-54 [PMID:8757340]

301. Rovati GE, Giovanazzi S, Mezzetti M and Nicosia S. (1992) Heterogeneity of binding sites for ICI 198,615 in human lung parenchyma. Biochem. Pharmacol. 44: 1411-5 [PMID:1329767]

302. Runarsson G, Liu A, Mahshid Y, Feltenmark S, Pettersson A, Klein E, Björkholm M and Claesson HE. (2005) Leukotriene B4 plays a pivotal role in CD40-dependent activation of chronic B lymphocytic leukemia cells. Blood 105: 1274-9 [PMID:15454480]

303. Sabirsh A, Bristulf $J$ and Owman C. (2004) Exploring the pharmacology of the leukotriene B4 receptor BLT1, without the confounding effects of BLT2. Eur. J. Pharmacol. 499: 53-65 [PMID:15363951]

304. Sadik CD, Kim ND, Iwakura Y and Luster AD. (2012) Neutrophils orchestrate their own recruitment in murine arthritis through $\mathrm{C} 5 \mathrm{aR}$ and FcyR signaling. Proc. Natl. Acad. Sci. U.S.A. 109: E3177-85 [PMID:23112187]

305. Saegusa S, Tsubone H and Kuwahara M. (2001) Leukotriene D(4)-induced Rho-mediated actin reorganization in human bronchial smooth muscle cells. Eur. J. Pharmacol. 413: 163-71 [PMID:11226389]

306. Saito K, Nagata M, Kikuchi I and Sakamoto Y. (2004) Leukotriene D4 and eosinophil transendothelial migration, superoxide generation, and degranulation via beta2 integrin. Ann. Allergy Asthma Immunol. 93: 594-600 [PMID:15609771]

307. Sakata K and Bäck M. (2002) Receptor preferences of cysteinyl-leukotrienes in the guinea pig lung parenchyma. Eur. J. Pharmacol. 436: 119-26 [PMID:11834255]

308. Sarau HM, Ames RS, Chambers J, Ellis C, Elshourbagy N, Foley JJ, Schmidt DB, Muccitelli RM, Jenkins $O$ and Murdock PR et al.. (1999) Identification, molecular cloning, expression, and characterization of a cysteinyl leukotriene receptor. Mol. Pharmacol. 56: 657-63 [PMID:10462554]

309. Sarveswaran S and Ghosh J. (2013) OXER1, a G protein-coupled oxoeicosatetraenoid receptor, mediates the survival-promoting effects of arachidonate 5-lipoxygenase in prostate cancer cells. Cancer Lett. 336: 185-95 [PMID:23643940]

310. Saussy Jr DL, Sarau HM, Foley JJ, Mong S and Crooke ST. (1989) Mechanisms of leukotriene E4 partial agonist activity at leukotriene D4 receptors in differentiated U-937 cells. J. Biol. Chem. 264: 19845-55 [PMID:2555334]

311. Sawmynaden P and Perretti M. (2006) Glucocorticoid upregulation of the annexin-A1 receptor in leukocytes. Biochem. Biophys. Res. Commun. 349: 1351-5 [PMID:16973129]

312. Schierle S, Flauaus C, Heitel P, Willems S, Schmidt J, Kaiser A, Weizel L, Goebel T, Kahnt AS and Geisslinger $G$ et al.. (2018) Boosting Anti-Inflammatory Potency of Zafirlukast by Designed Polypharmacology. J. Med. Chem. 61: 5758-5764 [PMID:29878767]

313. Schwenk U and Schröder JM. (1995) 5-Oxo-eicosanoids are potent eosinophil chemotactic factors. Functional characterization and structural requirements. J. Biol. Chem. 270: 15029-36 [PMID:7797484]

314. Seo JK, Choi SY, Kim Y, Baek SH, Kim KT, Chae CB, Lambeth JD, Suh PG and Ryu SH. (1997) A peptide with unique receptor specificity: stimulation of phosphoinositide hydrolysis and induction of superoxide generation in human neutrophils. J. Immunol. 158: 1895-901 [PMID:9029131] 
315. Serezani $\mathrm{CH}$, Aronoff DM, Sitrin RG and Peters-Golden M. (2009) FcgammaRI ligation leads to a complex with BLT1 in lipid rafts that enhances rat lung macrophage antimicrobial functions. Blood 114: 3316-24 [PMID:19657115]

316. Serhan CN. (2007) Resolution phase of inflammation: novel endogenous anti-inflammatory and proresolving lipid mediators and pathways. Annu. Rev. Immunol. 25: 101-37 [PMID:17090225]

317. Serhan CN and Petasis NA. (2011) Resolvins and protectins in inflammation resolution.Chem. Rev. 111: 5922-43 [PMID:21766791]

318. Shao WH, Del Prete A, Bock CB and Haribabu B. (2006) Targeted disruption of leukotriene B4 receptors BLT1 and BLT2: a critical role for BLT1 in collagen-induced arthritis in mice. J. Immunol. 176: 6254-61 [PMID:16670336]

319. Shen W, Proost P, Li B, Gong W, Le Y, Sargeant R, Murphy PM, Van Damme J and Wang JM. (2000) Activation of the chemotactic peptide receptor FPRL1 in monocytes phosphorylates the chemokine receptor CCR5 and attenuates cell responses to selected chemokines. Biochem. Biophys. Res. Commun. 272: 276-83 [PMID:10872839]

320. Sheng WW, Li CT, Zhang WP, Yuan YM, Hu H, Fang SH, Zhang L and Wei EQ. (2006) Distinct roles of CysLT1 and CysLT2 receptors in oxygen glucose deprivation-induced PC12 cell death. Biochem. Biophys. Res. Commun. 346: 19-25 [PMID:16756959]

321. Shin JA, Chang HS, Park SM, Jang AS, Park SW, Park JS, Uh ST, II Lim G, Rhim T and Kim MKet al.. (2009) Genetic effect of CysLTR2 polymorphisms on its mRNA synthesis and stabilization. BMC Med. Genet. 10: 106 [PMID:19840403]

322. Shirasaki H, Kanaizumi E, Seki N, Fujita M, Kikuchi M and Himi T. (2013) Localization and up-regulation of cysteinyl leukotriene-2 receptor in human allergic nasal mucosa. Allergol Int 62: 223-8 [PMID:23524649]

323. Showell HJ, Conklyn MJ, Alpert R, Hingorani GP, Wright KF, Smith MA, Stam E, Salter ED, Scampoli DN and Meltzer S et al.. (1998) The preclinical pharmacological profile of the potent and selective leukotriene B4 antagonist CP-195543. J. Pharmacol. Exp. Ther. 285: 946-54 [PMID:9618393]

324. Showell HJ, Pettipher ER, Cheng JB, Breslow R, Conklyn MJ, Farrell CA, Hingorani GP, Salter ED, Hackman BC and Wimberly DJ. (1995) The in vitro and in vivo pharmacologic activity of the potent and selective leukotriene B4 receptor antagonist CP-105696. J. Pharmacol. Exp. Ther. 273: 176-84 [PMID:7714764]

325. Simiele F, Recchiuti A, Mattoscio D, De Luca A, Cianci E, Franchi S, Gatta V, Parolari A, Werba JP and Camera $\mathrm{M}$ et al.. (2012) Transcriptional regulation of the human FPR2/ALX gene: evidence of a heritable genetic variant that impairs promoter activity. FASEB J. 26: 1323-33 [PMID:22131270]

326. Sjölander A, Grönroos E, Hammarström S and Andersson T. (1990) Leukotriene D4 and E4 induce transmembrane signaling in human epithelial cells. Single cell analysis reveals diverse pathways at the Gprotein level for the influx and the intracellular mobilization of Ca2+. J. Biol. Chem. 265: 20976-81 [PMID:2174431]

327. Sjöström M, Johansson AS, Schröder O, Qiu H, Palmblad J and Haeggström JZ. (2003) Dominant expression of the CysLT2 receptor accounts for calcium signaling by cysteinyl leukotrienes in human umbilical vein endothelial cells. Arterioscler. Thromb. Vasc. Biol. 23: e37-41 [PMID:12816881]

328. Skoglund G and Claesson HE. (1991) Intracellular mechanisms involved in leukotriene C4-stimulated adhesion of U-937 cells. Cell. Signal. 3: 399-404 [PMID:1760251]

329. Smith LJ, Greenberger PA, Patterson R, Krell RD and Bernstein PR. (1985) The effect of inhaled leukotriene D4 in humans. Am. Rev. Respir. Dis. 131: 368-72 [PMID:3883862]

330. Snyder DW and Krell RD. (1984) Pharmacological evidence for a distinct leukotriene C4 receptor in guinea-pig trachea. J. Pharmacol. Exp. Ther. 231: 616-22 [PMID:6094796]

331. Sodin-Semrl S, Spagnolo A, Barbaro B, Varga J and Fiore S. (2004) Lipoxin A4 counteracts synergistic activation of human fibroblast-like synoviocytes. Int $J$ Immunopathol Pharmacol17: 15-25 [PMID:15000862]

332. Sodin-Semrl S, Spagnolo A, Mikus R, Barbaro B, Varga J and Fiore S. (2004) Opposing regulation of interleukin-8 and NF-kappaB responses by lipoxin A4 and serum amyloid $A$ via the common lipoxin $A$ 
receptor. Int J Immunopathol Pharmacol 17: 145-56 [PMID:15171815]

333. Sodin-Semrl S, Taddeo B, Tseng D, Varga J and Fiore S. (2000) Lipoxin A4 inhibits IL-1 beta-induced IL6 , IL-8, and matrix metalloproteinase-3 production in human synovial fibroblasts and enhances synthesis of tissue inhibitors of metalloproteinases. J. Immunol. 164: 2660-6 [PMID:10679106]

334. Southgate EL, He RL, Gao JL, Murphy PM, Nanamori M and Ye RD. (2008) Identification of formyl peptides from Listeria monocytogenes and Staphylococcus aureus as potent chemoattractants for mouse neutrophils. J. Immunol. 181: 1429-37 [PMID:18606697]

335. Sozzani S, Zhou D, Locati M, Bernasconi S, Luini W, Mantovani A and O'Flaherty JT. (1996) Stimulating properties of 5-oxo-eicosanoids for human monocytes: synergism with monocyte chemotactic protein-1 and -3. J. Immunol. 157: 4664-71 [PMID:8906847]

336. Stalder AK, Lott D, Strasser DS, Cruz HG, Krause A, Groenen PM and Dingemanse J. (2017) Biomarkerguided clinical development of the first-in-class anti-inflammatory FPR2/ALX agonist ACT-389949. Br J Clin Pharmacol 83: 476-486 [PMID:27730665]

337. Stamatiou PB, Chan CC, Monneret G, Ethier D, Rokach J and Powell WS. (2004) 5-oxo-6,8,11,14eicosatetraenoic acid stimulates the release of the eosinophil survival factor granulocyte/macrophage colony-stimulating factor from monocytes. J. Biol. Chem. 279: 28159-64 [PMID:15136573]

338. Stanke-Labesque F, Molière P, Bessard J, Laville M, Véricel E and Lagarde M. (2008) Effect of dietary supplementation with increasing doses of docosahexaenoic acid on neutrophil lipid composition and leukotriene production in human healthy volunteers. Br. J. Nutr. 100: 829-33 [PMID:18304388]

339. Stanke-Labesque F, Pépin JL, de Jouvencel T, Arnaud C, Baguet JP, Petri MH, Tamisier R, Jourdil JF, Lévy P and Bäck M. (2012) Leukotriene B4 pathway activation and atherosclerosis in obstructive sleep apnea. J. Lipid Res. 53: 1944-51 [PMID:22761257]

340. Stenfeldt AL, Karlsson J, Wennerås C, Bylund J, Fu H and Dahlgren C. (2007) Cyclosporin H, Boc-MLF and Boc-FLFLF are antagonists that preferentially inhibit activity triggered through the formyl peptide receptor. Inflammation 30: 224-9 [PMID:17687636]

341. Stuart CA, Meehan RT, Neale LS, Cintron NM and Furlanetto RW. (1991) Insulin-like growth factor-I binds selectively to human peripheral blood monocytes and B-lymphocytes. J. Clin. Endocrinol. Metab. 72: 111722 [PMID:1850753]

342. Sturm GJ, Schuligoi R, Sturm EM, Royer JF, Lang-Loidolt D, Stammberger H, Amann R, Peskar BA and Heinemann A. (2005) 5-Oxo-6,8,11,14-eicosatetraenoic acid is a potent chemoattractant for human basophils. J. Allergy Clin. Immunol. 116: 1014-9 [PMID:16275369]

343. Su SB, Gao Jl, Gong Wh, Dunlop NM, Murphy PM, Oppenheim JJ and Wang JM. (1999) T21/DP107, A synthetic leucine zipper-like domain of the HIV-1 envelope gp41, attracts and activates human phagocytes by using G-protein-coupled formyl peptide receptors. J. Immunol. 162: 5924-30 [PMID:10229829]

344. Su SB, Gong W, Gao JL, Shen W, Murphy PM, Oppenheim JJ and Wang JM. (1999) A seventransmembrane, G protein-coupled receptor, FPRL1, mediates the chemotactic activity of serum amyloid A for human phagocytic cells. J. Exp. Med. 189: 395-402 [PMID:9892621]

345. Subbarao K, Jala VR, Mathis S, Suttles J, Zacharias W, Ahamed J, Ali H, Tseng MT and Haribabu B. (2004) Role of leukotriene B4 receptors in the development of atherosclerosis: potential mechanisms. Arterioscler. Thromb. Vasc. Biol. 24: 369-75 [PMID:14656734]

346. Sundaram S and Ghosh J. (2006) Expression of 5-oxoETE receptor in prostate cancer cells: critical role in survival. Biochem. Biophys. Res. Commun. 339: 93-8 [PMID:16289380]

347. Suzuki S, Takeuchi K, Ishinaga H, Basbaum C and Majima Y. (2008) Leukotriene D4 upregulates MUC2 gene transcription in human epithelial cells. Pharmacology 81: 221-8 [PMID:18176092]

348. Tager AM, Bromley SK, Medoff BD, Islam SA, Bercury SD, Friedrich EB, Carafone AD, Gerszten RE and Luster AD. (2003) Leukotriene B4 receptor BLT1 mediates early effector T cell recruitment. Nat. Immunol. 4: 982-90 [PMID:12949531]

349. Tager AM, Dufour JH, Goodarzi K, Bercury SD, von Andrian UH and Luster AD. (2000) BLTR mediates leukotriene $\mathrm{B}(4)$-induced chemotaxis and adhesion and plays a dominant role in eosinophil accumulation in a murine model of peritonitis. J. Exp. Med. 192: 439-46 [PMID:10934232] 
350. Takano T, Fiore S, Maddox JF, Brady HR, Petasis NA and Serhan CN. (1997) Aspirin-triggered 15-epilipoxin A4 (LXA4) and LXA4 stable analogues are potent inhibitors of acute inflammation: evidence for anti-inflammatory receptors. J. Exp. Med. 185: 1693-704 [PMID:9151906]

351. Takasaki J, Kamohara M, Matsumoto M, Saito T, Sugimoto T, Ohishi T, Ishii H, Ota T, Nishikawa T and Kawai $Y$ et al.. (2000) The molecular characterization and tissue distribution of the human cysteinyl leukotriene CysLT(2) receptor. Biochem. Biophys. Res. Commun. 274: 316-22 [PMID:10913337]

352. Taube C, Miyahara N, Ott V, Swanson B, Takeda K, Loader J, Shultz LD, Tager AM, Luster AD and Dakhama A et al.. (2006) The leukotriene B4 receptor (BLT1) is required for effector CD8+ T cell-mediated, mast cell-dependent airway hyperresponsiveness. J. Immunol. 176: 3157-64 [PMID:16493075]

353. Terawaki K, Yokomizo T, Nagase T, Toda A, Taniguchi M, Hashizume K, Yagi T and Shimizu T. (2005) Absence of leukotriene B4 receptor 1 confers resistance to airway hyperresponsiveness and Th2-type immune responses. J. Immunol. 175: 4217-25 [PMID:16177061]

354. Thompson C, Cloutier A, Bossé Y, Poisson C, Larivée P, McDonald PP, Stankova J and RolaPleszczynski M. (2008) Signaling by the cysteinyl-leukotriene receptor 2. Involvement in chemokine gene transcription. J. Biol. Chem. 283: 1974-84 [PMID:18048362]

355. Thompson C, Cloutier A, Bossé Y, Thivierge M, Gouill CL, Larivée P, McDonald PP, Stankova J and RolaPleszczynski M. (2006) CysLT1 receptor engagement induces activator protein-1- and NF-kappaBdependent IL-8 expression. Am. J. Respir. Cell Mol. Biol. 35: 697-704 [PMID:16809637]

356. Thompson MD, Capra V, Takasaki J, Maresca G, Rovati GE, Slutsky AS, Lilly C, Zamel N, Mclntyre Burnham W and Cole DE et al.. (2007) A functional G300S variant of the cysteinyl leukotriene 1 receptor is associated with atopy in a Tristan da Cunha isolate. Pharmacogenet. Genomics 17: 539-49 [PMID:17558309]

357. Thompson MD, Storm van's Gravesande K, Galczenski H, Burnham WM, Siminovitch KA, Zamel N, Slutsky A, Drazen JM, George SR and Evans JF et al.. (2003) A cysteinyl leukotriene 2 receptor variant is associated with atopy in the population of Tristan da Cunha. Pharmacogenetics 13: 641-9 [PMID:14515063]

358. Tiffany HL, Lavigne MC, Cui YH, Wang JM, Leto TL, Gao JL and Murphy PM. (2001) Amyloid-beta induces chemotaxis and oxidant stress by acting at formylpeptide receptor 2, a $\mathrm{G}$ protein-coupled receptor expressed in phagocytes and brain. J. Biol. Chem. 276: 23645-52 [PMID:11316806]

359. Toda A, Terawaki K, Yamazaki S, Saeki K, Shimizu T and Yokomizo T. (2010) Attenuated Th1 induction by dendritic cells from mice deficient in the leukotriene B4 receptor 1. Biochimie 92: 682-91 [PMID:20004699]

360. Toda A, Yokomizo T, Masuda K, Nakao A, Izumi T and Shimizu T. (1999) Cloning and characterization of rat leukotriene B(4) receptor. Biochem. Biophys. Res. Commun. 262: 806-12 [PMID:10471406]

361. Tudhope SR, Cuthbert NJ, Abram TS, Jennings MA, Maxey RJ, Thompson AM, Norman P and Gardiner PJ. (1994) BAYu9773, a novel antagonist of cysteinyl-leukotrienes with activity against two receptor subtypes. Eur. J. Pharmacol. 264: 317-323 [PMID:7698171]

362. Ueda T, Takeno S, Furukido K, Hirakawa K and Yajin K. (2003) Leukotriene receptor antagonist pranlukast suppresses eosinophil infiltration and cytokine production in human nasal mucosa of perennial allergic rhinitis. Ann. Otol. Rhinol. Laryngol. 112: 955-61 [PMID:14653364]

363. Urasaki T, Takasaki J, Nagasawa T and Ninomiya H. (2001) Pivotal role of 5-lipoxygenase in the activation of human eosinophils: platelet-activating factor and interleukin-5 induce CD69 on eosinophils through the 5-lipoxygenase pathway. J. Leukoc. Biol. 69: 105-12 [PMID:11200053]

364. Uzonyi B, Lötzer K, Jahn S, Kramer C, Hildner M, Bretschneider E, Radke D, Beer M, Vollandt R and Evans JF et al.. (2006) Cysteinyl leukotriene 2 receptor and protease-activated receptor 1 activate strongly correlated early genes in human endothelial cells. Proc. Natl. Acad. Sci. U.S.A. 103: 6326-31 [PMID:16606835]

365. Vannella KM, McMillan TR, Charbeneau RP, Wilke CA, Thomas PE, Toews GB, Peters-Golden M and Moore BB. (2007) Cysteinyl leukotrienes are autocrine and paracrine regulators of fibrocyte function. $J$. Immunol. 179: 7883-90 [PMID:18025235] 
366. Virchow Jr JC, Faehndrich S, Nassenstein C, Bock S, Matthys H and Luttmann W. (2001) Effect of a specific cysteinyl leukotriene-receptor 1-antagonist (montelukast) on the transmigration of eosinophils across human umbilical vein endothelial cells. Clin. Exp. Allergy 31: 836-44 [PMID:11422147]

367. Waechter V, Marti-Jaun J, Weber A, Madi ZL and Hersberger M. (2012) No evidence for the involvement of the lipoxin A4 receptor (FPR2/ALX) gene in the susceptibility to coronary artery disease. Clin. Chem. Lab. Med. 50: 177-9 [PMID:22734147]

368. Walch L, Norel X, Bäck M, Gascard JP, Dahlén SE and Brink C. (2002) Pharmacological evidence for a novel cysteinyl-leukotriene receptor subtype in human pulmonary artery smooth muscle. Br. J. Pharmacol. 137: 1339-45 [PMID:12466244]

369. Walther A, Riehemann K and Gerke V. (2000) A novel ligand of the formyl peptide receptor: annexin I regulates neutrophil extravasation by interacting with the FPR. Mol. Cell 5: 831-40 [PMID:10882119]

370. Wang ML, Huang XJ, Fang SH, Yuan YM, Zhang WP, Lu YB, Ding Q and Wei EQ. (2006) Leukotriene D4 induces brain edema and enhances CysLT2 receptor-mediated aquaporin 4 expression. Biochem.

Biophys. Res. Commun. 350: 399-404 [PMID:17010308]

371. Watanabe S, Yamasaki A, Hashimoto K, Shigeoka Y, Chikumi H, Hasegawa Y, Sumikawa T, Takata M, Okazaki R and Watanabe $\mathrm{M}$ et al.. (2009) Expression of functional leukotriene B4 receptors on human airway smooth muscle cells. J. Allergy Clin. Immunol. 124: 59-65.e1-3 [PMID:19477492]

372. Weiss JW, Drazen JM, Coles N, McFadden Jr ER, Weller PF, Corey EJ, Lewis RA and Austen KF. (1982) Bronchoconstrictor effects of leukotriene $C$ in humans. Science 216: 196-8 [PMID:7063880]

373. Weller CL, Collington SJ, Brown JK, Miller HR, Al-Kashi A, Clark P, Jose PJ, Hartnell A and Williams TJ. (2005) Leukotriene B4, an activation product of mast cells, is a chemoattractant for their progenitors. J. Exp. Med. 201: 1961-71 [PMID:15955837]

374. Winkler JD, Sarau HM, Foley JJ and Crooke ST. (1988) Leukotriene D4-induced homologous desensitization in basal and differentiated U-937 cells: characterization with the partial agonist leukotriene E4 and assessment of receptor reserve. J. Pharmacol. Exp. Ther. 247: 54-62 [PMID:2845060]

375. Woszczek G, Chen LY, Nagineni S, Kern S, Barb J, Munson PJ, Logun C, Danner RL and Shelhamer JH. (2008) Leukotriene $\mathrm{D}(4)$ induces gene expression in human monocytes through cysteinyl leukotriene type I receptor. J. Allergy Clin. Immunol. 121: 215-221.e1 [PMID:18028998]

376. Wunder F, Tinel H, Kast R, Geerts A, Becker EM, Kolkhof P, Hütter J, Ergüden J and Härter M. (2010) Pharmacological characterization of the first potent and selective antagonist at the cysteinyl leukotriene 2 (CysLT(2)) receptor. Br. J. Pharmacol. 160: 399-409 [PMID:20423349]

377. Yan D, Stocco R, Sawyer N, Nesheim ME, Abramovitz M and Funk CD. (2011) Differential signaling of cysteinyl leukotrienes and a novel cysteinyl leukotriene receptor $2\left(\mathrm{CysLT}_{2}\right)$ agonist, $\mathrm{N}$-methyl-leukotriene $\mathrm{C}_{4}$, in calcium reporter and $\beta$ arrestin assays. Mol. Pharmacol. 79: 270-8 [PMID:21078884]

378. Yang EM, Kim SH, Kim NH and Park HS. (2010) The genetic association of the FPRL1 promoter polymorphism with chronic urticaria in a Korean population. Ann. Allergy Asthma Immunol. 105: 96-7 [PMID:20642210]

379. Yang G, Haczku A, Chen H, Martin V, Galczenski H, Tomer Y, Van Besien CR, Evans JF, Panettieri RA and Funk CD et al.. (2004) Transgenic smooth muscle expression of the human CysLT1 receptor induces enhanced responsiveness of murine airways to leukotriene D4. Am. J. Physiol. Lung Cell Mol. Physiol. 286: L992-1001 [PMID:15064240]

380. Ye RD, Boulay F, Wang JM, Dahlgren C, Gerard C, Parmentier M, Serhan CN and Murphy PM. (2009) International Union of Basic and Clinical Pharmacology. LXXIII. Nomenclature for the formyl peptide receptor (FPR) family. Pharmacol. Rev. 61: 119-61 [PMID:19498085]

381. Ying G, Iribarren P, Zhou Y, Gong W, Zhang N, Yu ZX, Le Y, Cui Y and Wang JM. (2004) Humanin, a newly identified neuroprotective factor, uses the $G$ protein-coupled formylpeptide receptor-like-1 as a functional receptor. J. Immunol. 172: 7078-85 [PMID:15153530]

382. Yokomizo T, Izumi T, Chang K, Takuwa Y and Shimizu T. (1997) A G-protein-coupled receptor for leukotriene B4 that mediates chemotaxis. Nature 387: 620-4 [PMID:9177352]

383. Yokomizo T, Izumi T and Shimizu T. (2001) Co-expression of two LTB4 receptors in human mononuclear 
cells. Life Sci. 68: 2207-12 [PMID:11358329]

384. Yokomizo T, Kato K, Hagiya H, Izumi T and Shimizu T. (2001) Hydroxyeicosanoids bind to and activate the low affinity leukotriene B4 receptor, BLT2. J. Biol. Chem. 276: 12454-9 [PMID:11278893]

385. Yokomizo T, Kato K, Terawaki K, Izumi T and Shimizu T. (2000) A second leukotriene B(4) receptor, BLT2. A new therapeutic target in inflammation and immunological disorders. J. Exp. Med. 192: 421-32 [PMID:10934230]

386. Yokota $Y$, Inoue H, Matsumura Y, Nabeta H, Narusawa M, Watanabe A, Sakamoto C, Hijikata Y, IgaMurahashi $\mathrm{M}$ and Takayama $\mathrm{K}$ et al.. (2012) Absence of LTB4/BLT1 axis facilitates generation of mouse GM-CSF-induced long-lasting antitumor immunologic memory by enhancing innate and adaptive immune systems. Blood 120: 3444-54 [PMID:22936657]

387. Zhou C, Zhang S, Nanamori M, Zhang Y, Liu Q, Li N, Sun M, Tian J, Ye PP and Cheng \$t al.. (2007) Pharmacological characterization of a novel nonpeptide antagonist for formyl peptide receptor-like 1. Mol. Pharmacol. 72: 976-83 [PMID:17652444]

388. Zhu J, Qiu YS, Figueroa DJ, Bandi V, Galczenski H, Hamada K, Guntupalli KK, Evans JF and Jeffery PK. (2005) Localization and upregulation of cysteinyl leukotriene-1 receptor in asthmatic bronchial mucosa. Am. J. Respir. Cell Mol. Biol. 33: 531-40 [PMID:16123393] 